\title{
Implication of glycogen synthase kinase 3 in diabetes-associated islet inflammation
}

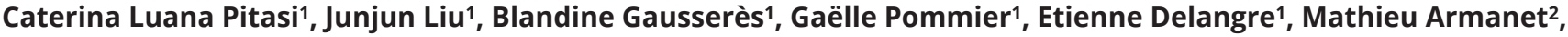 \\ Pierre Cattan², Bruno Mégarbane³, Anne-Sophie Hanak³, Kamel Maouche1, Danielle Bailbé1, Bernard Portha1 and \\ Jamileh Movassat ${ }^{1}$
}

1 Université Paris Diderot, BFA, UMR 8251, CNRS, Team 'Biologie et Pathologie du Pancréas Endocrine', Paris, France

${ }^{2}$ Cell Therapy Unit, Saint-Louis hospital, AP-HP, University Paris-Diderot, Paris, France

3INSERM UMRS1144, Université Paris-Descartes, Université Paris-Diderot, Paris, France

Correspondence should be addressed to J Movassat: movassat@univ-paris-diderot.fr

\begin{abstract}
Islet inflammation is associated with defective $\beta$ cell function and mass in type 2 diabetes (T2D). Glycogen synthase kinase 3 (GSK3) has been identified as an important regulator of inflammation in different diseased conditions. However, the role of GSK3 in islet inflammation in the context of diabetes remains unexplored. In this study, we investigated the direct implication of GSK3 in islet inflammation in vitro and tested the impact of GSK3 inhibition in vivo, on the reduction of islet inflammation, and the improvement of glucose metabolism in the Goto-Kakizaki (GK) rat, a spontaneous model of T2D. GK rats were chronically treated with infra-therapeutic doses of lithium, a widely used inhibitor of GSK3. We analyzed parameters of glucose homeostasis as well as islet inflammation and fibrosis in the endocrine pancreas. Ex vivo, we tested the impact of GSK3 inhibition on the autonomous inflammatory response of non-diabetic rat and human islets, exposed to a mix of pro-inflammatory cytokines to mimic an inflammatory environment. Treatment of young GK rats with lithium prevented the development of overt diabetes. Lithium treatment resulted in reduced expression of pro-inflammatory cytokines in the islets. It decreased islet fibrosis and partially restored the glucoseinduced insulin secretion in GK rats. Studies in non-diabetic human and rat islets exposed to inflammatory environment revealed the direct implication of GSK3 in the islet autonomous inflammatory response. We show for the first time, the implication of GSK3 in islet inflammation and suggest this enzyme as a viable target to treat diabetesassociated inflammation.
\end{abstract}

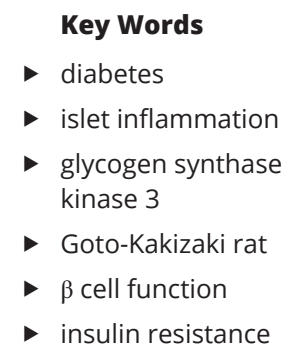

Journal of Endocrinology (2020) 244, 133-148

\section{Introduction}

Type 2 diabetes (T2D) is recognized as a state of chronic inflammation. In addition to systemic and adipose tissue inflammation (Dalmas et al. 2011), local inflammation within the endocrine pancreas has been established and reported to contribute to islet dysfunction in T2D (Donath et al. 2009, Richardson et al. 2009, Adugo et al. 2012,
Kamata et al. 2014, Westwell-Roper et al. 2014, Eguchi \& Nagai 2017). Studies in different T2D animal models such as mice fed with high-fat diet, $\mathrm{db} / \mathrm{db}$ mice (Ehses et al. 2007) and Goto-Kakizaki rats (HomoDelarche et al. 2006, Ehses et al. 2009) showed elevated number of macrophages within the islets. 
Immunohistochemical analysis of post-mortem pancreatic tissues of patients with T2D also revealed the presence of immune cells within the endocrine pancreas (Donath et al. 2008).

Diabetes-associated glucolipotoxicity has been shown to induce an inflammatory response in the islets, notably by inducing chronic production of high levels of IL-1 $\beta$ and other pro-inflammatory mediators by the islets (Donath et al. 2009, Maedler et al. 2009, Westwell-Roper et al. 2014). This state of chronic inflammation impairs $\beta$ cell function and survival, further deteriorating glucose homeostasis.

Therefore, the understanding of mechanisms that govern diabetes-associated islet inflammation, and the identification of molecular targets to dampen inflammation are of importance for the treatment of T2D (Esser et al. 2015, Mandrup-Poulsen 2018). Antiinflammatory strategies such as IL-1 receptor antagonism have been tested in clinical trials, with encouraging results (Larsen et al. 2007, Malozowski \& Sahlroot 2007), supporting the idea that anti-inflammatory drugs could be part of the therapeutic arsenal to treat diabetes. Interestingly, some of the drugs used for the treatment of T2D, such as thiazolidinediones (TZD), and GLP-1 proved to have anti-inflammatory properties, which could, in addition to their specific anti-diabetic effects, provide increased benefit for the patients (Scheen et al. 2015).

Glycogen synthase kinase 3 (GSK3), with its two isoforms GSK3 $\alpha$ and GSK3 $\beta$, is a multi-tasking serinethreonine kinase which regulates crucial cellular functions such as proliferation, cell mobility and survival (EldarFinkelman 2002). In recent years, GSK3 $\beta$ has been found to be an important regulator of inflammation, adding yet another feature to the activities of this multifaceted enzyme (Jope et al. 2007).

GSK3 inhibitors have been reported to reduce the systemic inflammatory response, renal dysfunction, and hepatotoxicity associated with endotoxemia in rats (Dugo et al. 2005). In other inflammatory conditions, such as experimentally induced colitis in rats (Whittle et al. 2006) and arthritis caused by administration of type II collagen in mice (Cuzzocrea et al. 2006), GSK3 inhibitors diminished also the inflammatory response.

However, to date, the implication of GSK3 in diabetesassociated islet inflammation has not been explored. The Goto-Kakizaki (GK) rat is a spontaneous model of T2D originally established by inbreeding Wistar rats selected at the upper limit of normal glucose tolerance (Goto et al. 1976). We have shown that adult GK rats have a pronounced impairment of their $\beta$ cell mass and function, along with moderate peripheral insulin resistance (Portha et al. 2009). Importantly, $\beta$ cell dysfunction in GK rats is associated with islet inflammation, macrophage infiltration and fibrosis (Movassat et al. 1995, Homo-Delarche et al. 2006, Ehses et al. 2009). These characteristics, close to those of human T2D, make the GK model a suitable tool to address the role of islet inflammation in the pathogenesis of diabetes and to test novel anti-inflammatory strategies.

The aim of this study was to determine whether GSK3 is implicated in islet inflammation both in rat and human islets and to assess the effects of chronic in vivo inhibition of GSK3, on the improvement of islet inflammation and the alleviation of diabetic condition in the GK rat.

\section{Materials and methods}

\section{Chemicals and products}

RPMI 1640 GlutaMAX medium, penicillin-streptomycin, 2-mercaptoethanol were purchased from Life Technology. CMRL 1066 medium, fetal bovine serum, fetal calf serum, Hepes buffer, sodium pyruvate, collagenase type XI, Histopaque 1077 and Direct Red 80 were from SigmaAldrich. Rat recombinant cytokines and PVDF membranes were purchased from Millipore. Lithium chloride ( $\mathrm{LiCl}$ ) and SB216763 were purchased from Sigma-Aldrich. BSA was from Interchim (Montluçon, France). Papanicolau's solution (1a Harris' hematoxylin solution) was from Merck (ST Quentin en Yvelines, France). Human insulin was from Novo Nordisk A/S. Maxima Reverse Transcriptase was from ThermoFisher; random hexamer primers were from Invitrogen and KAPA FAST SYBR Green 480 kit was from Cliniscience (Nanterre, France). ELISA kit for insulin measurement was from ALPCO/Eurobio (Les Ulis, France); RNeasy mini kit and RNeasy micro kit were from Qiagen. Anti-phospho-STAT3 (Tyr 705), anti-phospho-GSK3 $\beta$ (Ser9) and anti-STAT3 antibodies were purchased from Cell Signaling. Anti-GSK3 $\beta$ antibody was from Millipore; anti- $\beta$-actin antibody was from Sigma-Aldrich; HRPconjugated biotinylated anti-mouse antibody was from VectorLabs, Eurobio (Les Ulis, France). Anti-insulin, HRPconjugated anti-guinea pig and anti-CD68 antibodies were from Abcam.

\section{Animals and in vivo treatments}

Goto-Kakizaki (GK) and Wistar male rats were obtained from our local colony maintained at the University ParisDiderot animal facility (Goto et al. 1976, Portha et al. 2009). All animal studies were conducted in accordance with EU 
directive 2010/63/UE for animal experiments and were approved by Buffon Ethical Committee (No. B75-13-17). Rats were housed in a controlled environment (temperature $=20 \pm 1^{\circ} \mathrm{C}$; humidity $=60 \%$ ) with unlimited access to food and water on 12-h light/dark cycle. At weaning, the animals were provided with a standard chow diet (diet A04, SAFE, Villemoisson-sur-Orge, France). GK and Wistar rats were treated with lithium chloride $(\mathrm{LiCl})$, a well-known inhibitor of GSK3 (GK/Li and Wistar/Li groups, respectively) or not (GK and Wistar groups, respectively), starting 1 week after weaning (5 weeks of age). The treatment was administered by the addition of $\mathrm{LiCl}(600 \mathrm{mg} / \mathrm{L})$ in drinking water, for 6 or 11 consecutive weeks. The dose of lithium was determined based on the literature, using the same route of administration (drinking water) and in a chronic manner (Omata et al. 2008, Talab et al. 2010). For all animals included in the study, during the treatment, body weight, water and food consumption were monitored twice a week, blood glucose levels were monitored once a week. Blood glucose levels were measured at non-fasting state (09:00), in conscious animals. Glycated hemoglobin (HbA1c) was determined by Cobas B 101 Analyzer (Roche Diagnostic). Lithium quantification was performed using inductively coupled plasma mass spectrometry (ICP-MS, Elan DRCe Perkin Elmer) by standard addition calibration as previously reported (Hanak et al. 2015). The limit of detection (determined as the standard deviation of the apparent concentration of the blanks) and the limit of quantification (determined as three times this value) were 0.2 and $0.6 \mathrm{nmol} / \mathrm{L}$, respectively.

At the end of the treatment, in some animals, pancreas was taken for histological studies, in others, for measurement of pancreatic insulin content, or islet isolation. Epididymal fat, liver, and soleus muscle were taken for gene expression studies. In another set of experiments, GK rats with established diabetes were divided into two groups, at the age of 10 weeks. One group was treated with $\mathrm{LiCl}$. The other group was untreated. Blood glucose level was monitored once a week in both groups.

\section{Rat islet isolation}

Pancreas from 10-12 weeks old GK, GK/Li, Wistar and Wistar/Li rats were digested by collagenase type XI $\left(37^{\circ} \mathrm{C}\right.$ for $10^{\prime}$ ) and isolated as previously described (Liu et al. 2015). Islets were hand-picked under a stereomicroscope and divided into different batches to be used for insulin secretion studies or to be stored at $-80^{\circ} \mathrm{C}$ until being used for mRNA and protein determination.

\section{Measurement of glucose-induced insulin secretion}

After islet isolation and hand picking, the islets were incubated in Krebs buffer for $1 \mathrm{~h}$ to allow for recovery and equilibration. Batch of ten islets isolated from GK and $\mathrm{GK} / \mathrm{Li}$ rats were then pre-incubated in KRBH (KrebsRinger/bicarbonate/HEPES) containing $0.2 \%$ fatty-acidfree BSA with $5.5 \mathrm{mM}$ glucose for $60^{\prime}$, followed by $90^{\prime}$ incubation in KRBH $0.2 \%$ BSA with $5.5 \mathrm{mM}$ or $16.7 \mathrm{mM}$ glucose to measure glucose-induced insulin secretion (GIIS). Fractions were then collected and stored at $-20^{\circ} \mathrm{C}$ to be used for the determination of insulin concentration in the media by ELISA (ALPCO) (Eurobio, Les Ulis, France).

\section{Insulin tolerance test}

After 6-h fasting, insulin tolerance tests (ITTs) were performed on non-anaesthetized 10-week-old GK and Wistar rats, treated or not with $\mathrm{LiCl}$. Human insulin was injected subcutaneously at the dose of $0.5 \mathrm{U} / \mathrm{kg}$ body weight. Samples of blood were collected at the tail vein before, and 30, 60, and 90 min after administration of insulin. Blood glucose concentrations were determined using an Accu-Chek Glucometer (Roche).

\section{Glucose tolerance test}

After 6-h fasting, oral glucose tolerance tests (OGTTs; $2 \mathrm{~g}$ glucose/kg body weight) were performed on nonanaesthetized 10-week-old rats. Blood were collected at the tail vein before, and 15, 30, 60, 90 and 120 min after administration of glucose. Blood glucose concentrations were determined using an Accu-Chek Glucometer (Roche).

\section{Rat islets culture and treatments}

Islets from 10 to 12-week-old Wistar rats were isolated as described earlier. Islets were transferred into culture dishes and cultured in RPMI 1640 medium as described previously (Liu et al. 2015). After 24-h culture in normal medium, Wistar islets were pre-treated with $10 \mathrm{mM} \mathrm{LiCl}$ ( $\mathrm{LiCl}$ group) overnight or not treated (NT group). Then, islets from NT and $\mathrm{LiCl}$ groups were incubated for $8 \mathrm{~h}$ with a mix of cytokines ( $500 \mathrm{U} / \mathrm{mL}$ TNF- $\alpha, 100 \mathrm{U} / \mathrm{mL}$ IFN $\gamma$, $50 \mathrm{U} / \mathrm{mL} \mathrm{IL}-1 \beta$ ) (CK and $\mathrm{CK}+\mathrm{LiCl}$ groups, respectively). The concentrations of cytokines used in this study were based on previous experiments by our team (Liu J \& Portha $\mathrm{B}$, unpublished observations). Islets were then processed for quantitative real-time PCR analysis to evaluate the expression of pro-inflammatory markers. 


\section{INS-1 832/13 $\beta$ cell culture and treatments}

The rat insulinoma $\beta$ cell line INS-1832/13 was used between passages 20 and 30. As described previously (Liu et al. 2015) and detailed in the Supplementary Materials (see section on supplementary materials given at the end of this article). After 48-72 h culture, INS- 1 cells with $\sim 70 \%$ confluence in six-well plates were pre-treated ( $\mathrm{LiCl}$ group) or not (no-treatment, NT group) for $1 \mathrm{~h}$ with an inhibitor of GSK3, lithium chloride ( $\mathrm{LiCl}$ ) at $10 \mathrm{mM}$. Then a mix of cytokines $(500 \mathrm{U} / \mathrm{mL}$ TNF- $\alpha, 100 \mathrm{U} / \mathrm{mL}$ IFN $\gamma, 50 \mathrm{U} / \mathrm{mL}$ IL-1 $\beta$ ) was added in the culture media of cells of both $\mathrm{NT}$ and $\mathrm{LiCl}$ groups $(\mathrm{CK}$ and $\mathrm{CK}+\mathrm{LiCl}$ groups, respectively) for $16 \mathrm{~h}$. Cells were then processed for quantitative real-time PCR analysis to evaluate the expression of pro-inflammatory markers. In other cells, pre-treated ( $\mathrm{LiCl}$ group) or not (NT group) were exposed to a mix of cytokines as described earlier (noted $\mathrm{CK}+\mathrm{LiCl}$ and CK, respectively), for $30 \mathrm{~min}, 2 \mathrm{~h}$ or $6 \mathrm{~h}$. At each time point, cell lysates were prepared to be used for Western blot analysis.

\section{Human islets culture and treatments}

Human islets were isolated from four brain-dead nondiabetic donors with prior consent for research use at Saint-Louis Hospital (Paris, France) according to a modified version of the automated method (Ricordi et al. 1988, Bucher et al. 2005). The isolated islets were washed and cultured in non-adherent culture flasks in CMRL 1066 medium, which contained $5.6 \mathrm{mM}$ glucose, $25 \mathrm{mM}$ HEPES, $2 \mathrm{mM}$ glutamine, $100 \mathrm{U} / \mathrm{mL}$ penicillin, $100 \mathrm{mg} / \mathrm{mL}$ streptomycin, and $10 \%$ fetal calf serum. After reception, human islets were cultured for an additional 48-h for recovery in our laboratory. Then, a group of islets was treated for $16 \mathrm{~h}$ with inhibitors of GSK3 $\mathrm{LiCl}(10 \mathrm{mM})$ or SB216763 $(20 \mu \mathrm{M})(\mathrm{LiCl}$ and SB groups, respectively). Another group was not treated and used as control (no-treatment, NT group). Then, cytokines $(500 \mathrm{U} / \mathrm{mL}$ TNF- $\alpha, 100 \mathrm{U} / \mathrm{mL}$ IFN $\gamma, 50 \mathrm{U} / \mathrm{mL}$ IL- $1 \beta$ ) were added in the medium of some islets of NT, $\mathrm{LiCl}$, and SB groups (CK, $\mathrm{CK}+\mathrm{LiCl}, \mathrm{CK}+\mathrm{SB}$ groups, respectively) for $8 \mathrm{~h}$. Islets were then processed for quantitative real-time PCR analysis to evaluate the expression of pro-inflammatory markers.

\section{Gel electrophoresis and Western blotting}

Whole tissue lysates were prepared by sonication in a lysis buffer. Twenty micrograms of proteins were resolved on 10\% SDS PAGE and then transferred to PVDF membranes as previously described (Figeac et al. 2010).
Details of immunoblotting are described in the Supplementary Materials.

\section{Quantitative real-time PCR}

Total RNA was extracted from rat and human islets using RNeasy micro kit, and from adipose tissue, skeletal muscle, liver and INS-1 cells using the RNeasy mini kit. cDNA of each RNA sample was synthesized with Maxima Reverse Transcriptase, using random hexamer primers. The primers were designed using OLIGO7 (the primer sets are described in Tables 1 and 2). Quantitative realtime PCR amplification reactions were carried out in a Light Cycler 480 (Roche Applied Science) using the KAPA FAST SYBR Green 480 kit as previously described (Liu et al. 2015) and detailed in the Supplementary Materials. mRNA transcript levels of four housekeeping genes (rpL19 (ribosomal protein L19), TBP (TATA-box-binding protein), cyclophilin A, HPRT1 (Hypoxanthine Phosphoribosyl

Table 1 List of rat primers used in this study.

\begin{tabular}{|c|c|c|}
\hline \multirow{3}{*}{$\frac{\text { Gene }}{\text { IL } 1-\beta}$} & \multicolumn{2}{|r|}{ Sequences } \\
\hline & $\mathrm{F}$ & GCACAGACCTGTCTTCCTAGGAAA \\
\hline & $\mathrm{R}$ & CCTGGGGAAGGCATTAGGAATA \\
\hline \multirow[t]{2}{*}{ IL-6 } & $\mathrm{F}$ & CCCTTCAGGAACAGCTATGAA \\
\hline & $\mathrm{R}$ & ACAACATCAGTCCCAAGAAGG \\
\hline \multirow[t]{2}{*}{ TNF- $\alpha$} & $\mathrm{F}$ & GGGGCCTCCAGAACTCCA \\
\hline & $\mathrm{R}$ & GGAGCCCATTTGGGAACTTCT \\
\hline \multirow[t]{2}{*}{ Ifit1 } & $\mathrm{F}$ & TTTCGGGTTTTCTTGGTTGTTGT \\
\hline & $\mathrm{R}$ & TCCAGTAAGCCAAACGTCT \\
\hline \multirow[t]{2}{*}{$\mathrm{BCL} 2$} & $\mathrm{~F}$ & CGGTGGTGGAGGAACTCTTCA \\
\hline & $\mathrm{R}$ & CTGGGGCCATATAGTTCCACAA \\
\hline \multirow[t]{2}{*}{ BAX } & $\mathrm{F}$ & GCTCAAGGCCCTGTGCACTAA \\
\hline & $\mathrm{R}$ & GTGAGGACTCCAGCCACAAAGA \\
\hline \multirow[t]{2}{*}{ iNOS } & $\mathrm{F}$ & GGCAATGGAGAGATTTTTCACGAC \\
\hline & $\mathrm{R}$ & TCTGGGTCCTCTGGTCAAAC \\
\hline \multirow[t]{2}{*}{ TLR-2 } & $\mathrm{F}$ & AAAGTAGAAACGGTAACAATACGG \\
\hline & $\mathrm{R}$ & СTCTTCAACCATCAGATTTTCGC \\
\hline \multirow[t]{2}{*}{ TLR-4 } & $\mathrm{F}$ & GACTCCATTCAAGCCCAAGCC \\
\hline & $\mathrm{R}$ & TTCTCCCAAGATCAACCGATGGAC \\
\hline \multirow[t]{2}{*}{ Ostepontin } & $\mathrm{F}$ & TGATGAACAGTATCCCGATGCCACA \\
\hline & $\mathrm{R}$ & CTGGCCCTCTGCTTATACTCCTTGG \\
\hline \multirow[t]{2}{*}{ CXCL1 } & $\mathrm{F}$ & AGAAAGAAGATAGATTGCACCGAT \\
\hline & $\mathrm{R}$ & ACGAGATATTTAACGCCTACCATC \\
\hline \multirow[t]{2}{*}{ CCL2 } & $\mathrm{F}$ & TCСАСТСТСТTTTCCACAACCACC \\
\hline & $\mathrm{R}$ & ACACAAAGTTTACCCATTCATCTCT \\
\hline \multirow[t]{2}{*}{ CCL3 } & $\mathrm{F}$ & AGAGGCAGCGAGTACCAGTC \\
\hline & $\mathrm{R}$ & AACAGAGGGTGCGCTTGTCA \\
\hline \multirow[t]{2}{*}{ rpL19 } & $\mathrm{F}$ & GCTGAGGCTCGCAGGTCTAA \\
\hline & $\mathrm{R}$ & CAGACACGAGGGACGCTTCA \\
\hline \multirow[t]{2}{*}{ TBP } & $\mathrm{F}$ & CGTGAATCTTGGCTGTAAACTTGA \\
\hline & $\mathrm{R}$ & GCTGCTAGTCTGGATTGTTCTTCA \\
\hline \multirow[t]{2}{*}{ Cyclophilin A } & $\mathrm{F}$ & AACCCACCGTGTTCTTC \\
\hline & $\mathrm{R}$ & TGCCTTCTTTCACCTTCCC \\
\hline \multirow{2}{*}{ HPRT1 } & $\mathrm{F}$ & TTGTTGGATATGCCCTTGACT \\
\hline & $\mathrm{R}$ & CCGCTGTCTTTTAGGCTTTG \\
\hline
\end{tabular}


Table 2 List of human primers used in this study.

\begin{tabular}{|c|c|c|}
\hline \multirow{3}{*}{$\frac{\text { Gene }}{\text { IL } 1-\beta}$} & \multicolumn{2}{|r|}{ Sequences } \\
\hline & $F$ & CGGCATCCAGCTACGAAT \\
\hline & $\mathrm{R}$ & GCCTCGTTATCCCATGTGTCGAA \\
\hline \multirow[t]{2}{*}{ IL-6 } & $\mathrm{F}$ & CCCACACAGACAGCCACTCAC \\
\hline & $\mathrm{R}$ & AGGCAAGTCTCCTCATTGAATCCA \\
\hline \multirow[t]{2}{*}{ IL-10 } & $\mathrm{F}$ & GAAGAATGCCTTTAATAAGCTCCA \\
\hline & $\mathrm{R}$ & CAGAGCCCCAGATCCGATT \\
\hline \multirow[t]{2}{*}{ TNF- $\alpha$} & $\mathrm{F}$ & CAGCTCCCTCTATTTATGTTTGCAC \\
\hline & $\mathrm{R}$ & GCCTATTGTTCAGCTCCGTTT \\
\hline \multirow[t]{2}{*}{ iNOS } & $\mathrm{F}$ & CATTCAGATCCCCAAGCTCTACAC \\
\hline & $\mathrm{R}$ & ATTCTGCCGAGATTTGAGCC \\
\hline \multirow[t]{2}{*}{ Ostepontin } & $\mathrm{F}$ & TGAAACCCACAGCCACAAGCA \\
\hline & $\mathrm{R}$ & СTTCCTTACTTTTGGGGTCTACAAC \\
\hline \multirow[t]{2}{*}{ CXCL8 } & $\mathrm{F}$ & CAGTTTTGCCAAGGAGTGCTA \\
\hline & $\mathrm{R}$ & АСTTCTCCACAACССТCTG \\
\hline \multirow[t]{2}{*}{ CCL2 } & $\mathrm{F}$ & GAGACTAACCCAGAAACATCCAA \\
\hline & $\mathrm{R}$ & TCACAGCTTCTTTGGGACACTTG \\
\hline \multirow[t]{2}{*}{ TBP } & $\mathrm{F}$ & GCACCACTCCACTGTATCCC \\
\hline & $\mathrm{R}$ & ATGATTACCGCAGCAAACCG \\
\hline \multirow[t]{2}{*}{ Cyclophilin A } & $\mathrm{F}$ & CACCGCACCCTACCTCAT \\
\hline & $\mathrm{R}$ & GACCTACAGCCTAAAGCCCAAT \\
\hline
\end{tabular}

transferase 1)) were assayed for rats. On the base on the stability of the different genes, cyclophilin A was retained for normalization of transcripts in INS-1 cells, rat pancreatic islets and liver, HPRT1 in adipose tissue and TBP in skeletal muscle. For human islets, mRNA transcript levels of two housekeeping genes (TBP and cyclophilin A) were assayed and cyclophilin A was retained for normalization of transcripts in islets.

\section{Pancreatic insulin content}

For determination of insulin content, pancreases were homogenized in an acid/alcohol solution (75\% ethanol, $1.5 \% \mathrm{HCl} 32.5 \mathrm{M}$ and $23.5 \%$ distilled water) and incubated at $4^{\circ}$ overnight. Then, the lysates were centrifuged $(1500 \mathrm{~g})$ at $4^{\circ} \mathrm{C}$. The supernatant fraction was stored at $-20^{\circ} \mathrm{C}$ until insulin was assayed by ELISA.

\section{Histological studies}

Tissues were collected at the end of the protocol and processed for histology as previously described (Figeac et al. 2010).

\section{Histomorphometric studies}

Serial pancreatic sections were stained for insulin and $\beta$ cell area and $\beta$ cell mass were evaluated as described in Figeac et al. (2010). At least eight sections were analyzed for each pancreas.

\section{Macrophage immunolocalization}

Serial pancreatic sections were blocked for $1 \mathrm{~h}$ with $10 \%$ normal goat serum in Tris buffer, after antigen retrieval for $30^{\prime}$ in a citrate buffer $\left(\mathrm{pH}\right.$ 6) at $100^{\circ} \mathrm{C}$ as previously described (Figeac et al. 2012). Sections were then incubated with anti-CD68 primary antibody (1:150) followed by incubation with HRP-conjugated biotinylated anti-mouse secondary antibody (1:200). Islets with more than three $\mathrm{CD}^{+}{ }^{+}$cells were counted as infiltrated islets, as described previously (Ehses et al. 2009). The results are expressed as percentage of infiltrated islets over the total number of islets. At least six sections were analyzed for each pancreas.

\section{Analysis of islet fibrosis}

Pancreatic sections were stained with Picro Sirius Red Solution (Direct Red 80). For details see the Supplementary Materials.

\section{Data and statistical analysis}

Results are expressed as means \pm s.E.M. The statistical significance between means was assessed by Student $t$ test or by ordinary one-way ANOVA followed by Tukey's multiple comparisons test when more than two groups were compared. Two-way ANOVA followed by Tukey post hoc analysis was used when more than two conditions were compared. $P$ value $<0.05$ was considered significant.

\section{Results}

We have previously shown that islet dysfunction in diabetic GK rats is associated with inflammation and fibrosis (Movassat et al. 1995, Homo-Delarche et al. 2006). Here, we set out to determine whether a chronic treatment with $\mathrm{LiCl}$ can reduce islet inflammation and prevent the development of diabetes.

\section{Lithium treatment does not alter basic physiological parameters in rats}

Animal were treated chronically with lithium, a wellknown and widely used inhibitor of GSK3 (EldarFinkelman \& Martinez 2011, King et al. 2014). Although other more selective inhibitors of GSK3 are available (i.e SB216763 or CHIR99021), their use in this study was not feasible, because of the extremely high cost of the amount needed for the chronic in vivo treatment (11 weeks). Moreover, in our previous works we have demonstrated that the treatment with $\mathrm{LiCl}$ was well tolerated by the 
animals, and it produced the same biological effects as those caused by specific inhibition of GSK3 $\beta$ using antiGSK3 $\beta$ morpholino-oligonucleotides (Figeac et al. 2010, 2012). All throughout the study, there were no increased mortality or macroscopic damages associated with lithium therapy, demonstrating that at the doses used in this study, lithium had no toxicity for the animals. In order to determine the potential impact of lithium in basic physiological parameters, we monitored the body weight and water and food intake, all throughout the study. There was no difference in the body weight between the GK and the lithium-treated GK (GK/Li) groups (Fig. 1A). Food consumption was similar between the two groups (Supplementary Fig. 1A). Water intake was increased in the control GK rats compared to GK/Li rats from the age of 9 weeks on (Supplementary Fig. 1B), along with the development of overt hyperglycemia in this group. There was no significant difference in water and food consumption between Wistar and Wistar/Li groups (Supplementary Fig. 1A and B). As described previously (Movassat et al. 1995), Wistar rats have higher body weight compared to age-matched GK rats (Fig. 1A). Accordingly, higher food intake was observed in Wistar compared to both GK groups (Supplementary Fig. 1A). However, once calculated as $\mathrm{g} / \mathrm{g}$ body weight, food intake was comparable between Wistar and GK groups (Supplementary Fig. 1C). As for the water intake, when calculated as $\mathrm{g} / \mathrm{g}$ body weight, water consumption was higher in the GK group compared to Wistar group (Fig. 1C), because of their elevated glycemia. Together, these results demonstrate that lithium treatment per se does not alter basic physiological parameters in rats.

\section{Measurement of plasma lithium concentrations}

Plasma lithium levels measured after 6 weeks of treatment were $0.145 \pm 0.02 \mathrm{mmol} / \mathrm{L}$ in GK/Li rats and $0.19 \pm 0.01$ $\mathrm{mmol} / \mathrm{L}$ in Wistar/Li rats. Lithium was undetectable in the plasma samples of untreated GK and Wistar rats.

\section{Lithium treatment prevents the development of overt hyperglycemia in GK rats}

The blood glucose level was monitored weekly, at 09:00 h. The glycemia of Wistar and Wistar/Li groups were similar all throughout the experiments (Fig. 1B). Before starting the treatment, 5-week-old GK rats were randomly divided in two groups: untreated GK group to be used as controls, and GK/Li group to receive the treatment. At that point, both groups exhibited moderate hyperglycemia
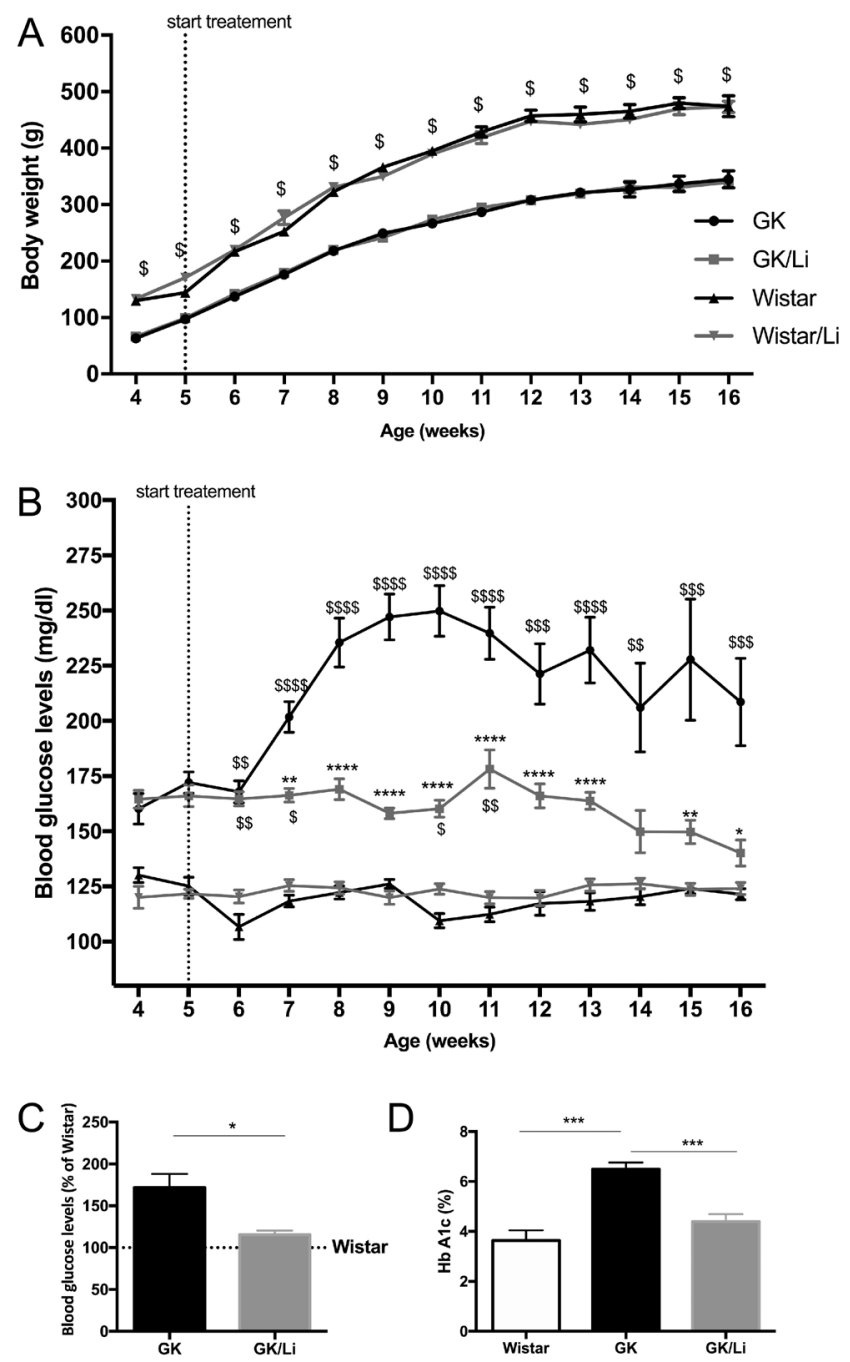

Figure 1

GSK3 inhibition prevents overt hyperglycemia in the GK rat. (A) Body weight and (B) blood glucose levels in GK and Wistar rats treated with $\mathrm{LiCl}$ (GK/Li, $n=40$; Wistar/Li, $n=12$ ) and in respective controls (GK, $n=40$; Wistar, $n=12$ ). (C) At the end of the treatment (11 weeks of treatments), the glycemia of GK/Li and GK rats was calculated as the percentage of the glycemia of non-diabetic Wistar rats and (D) the \% of glycated hemoglobin was determined. (A) $\$ P<0.001 \mathrm{GK}$ and GK/Li compared to Wistar and Wistar/Li rats. (B, C and D) $* P<0.05 ; * * P<0.01 ; * * * * P<0.0001$ compared to untreated GK rats; $\$ P<0.05 ; \$ \$ P<0.01 ; \$ \$ P<0.001 ; \$ \$ \$ P<0.0001$ compared to Wistar rats. Results are expressed as means \pm S.E.M. Two-way ANOVA with Tukey's multiple comparisons test (A and B), unpaired Student $t$ test (C) and ordinary one-way ANOVA followed by Tukey's multiple comparisons test (D) were used for statistical analysis.

$(166 \pm 11 \mathrm{mg} / \mathrm{dL}$ and $172 \pm 5 \mathrm{mg} / \mathrm{dL}$, respectively) as compared to age-matched non-diabetic Wistar rats $(125 \pm 4 \mathrm{mg} / \mathrm{dL}$ for Wistar group and $121 \pm 2 \mathrm{mg} / \mathrm{dL}$ for Wistar/Li). During the following days, the untreated GK rats started to exhibit higher glycemia, which led to overt diabetes $(>200 \mathrm{mg} / \mathrm{dL})$ at 7 weeks of age, and increased throughout the course of the study. Interestingly, in 
the GK/Li group, the mild hyperglycemia exhibited at the beginning of the treatment, tended to decline toward the end of the study (Fig. 1B). Thus, at the end point of the experiments, control GK rats had overt hyperglycemia compared to age-matched non-diabetic Wistar rats, while the GK/Li rats had near-normal glycemic values (Fig. 1C). Accordingly, the Hb1Ac levels in GK/Li rats were significantly decreased compared to control GK rats, bringing this parameter to a level similar to that found in non-diabetic Wistar rats (Fig. 1D). The whole-body insulin sensitivity evaluated by an insulin tolerance test showed that GK rats treated with $\mathrm{LiCl}$ had a significant improvement of their insulin sensitivity, compared to age-matched untreated GK rats (Fig. 2A). The glucose tolerance test revealed a slight but nonsignificant improvement of glucose profile during the test, in GK/Li rats compared to untreated GK rats (Fig. $2 \mathrm{~B})$, despite the fact that the glycemia of the animals used for the OGTT were significantly reduced in GK/Li compared to untreated GK rats $(171 \pm 7 \mathrm{mg} / \mathrm{dL}$ and $300 \pm 25 \mathrm{mg} / \mathrm{dL}$ respectively). The failure to see a positive effect for lithium on glucose tolerance could be due to insufficient statistical power. Indeed, as post-load glucose levels are more heterogenous than those determined in the fasting state, the relatively limited number of animals used for OGTT might account for the lack of statistical significance. However, we cannot exclude that some of the mechanisms involved in glucose intolerance in the GK model could remain unaffected by lithium therapy.

As for non-diabetic rats, there were no significant differences in ITT and OGTT profiles between Wistar and Wistar/Li groups (Fig. 2A and B).

\section{Lithium treatment reduces islet inflammation in GK rats}

In order to investigate the effects of lithium on islet inflammation, after 6 weeks of treatment, islets were isolated from pancreases of untreated GK, GK/Li, and Wistar rats. First, we showed that systemic lithium administration inhibited the pancreatic GSK3 $\beta$ as revealed by the increased amount of Ser9-phosphorylated GSK3 $\beta$ which represents the inactive form of the enzyme (Supplementary Fig. 2). Next, we assessed the expression of pro-inflammatory mediators in the islets. We found that the expression of pro-inflammatory cytokines IL- $1 \beta$, TNF- $\alpha$ and IL- 6 was dramatically increased in the islets of GK control rats as compared to age-matched Wistar rats (Fig. 3A, B and C), in keeping with our previous report (Lacraz et al. 2009). Importantly, chronic
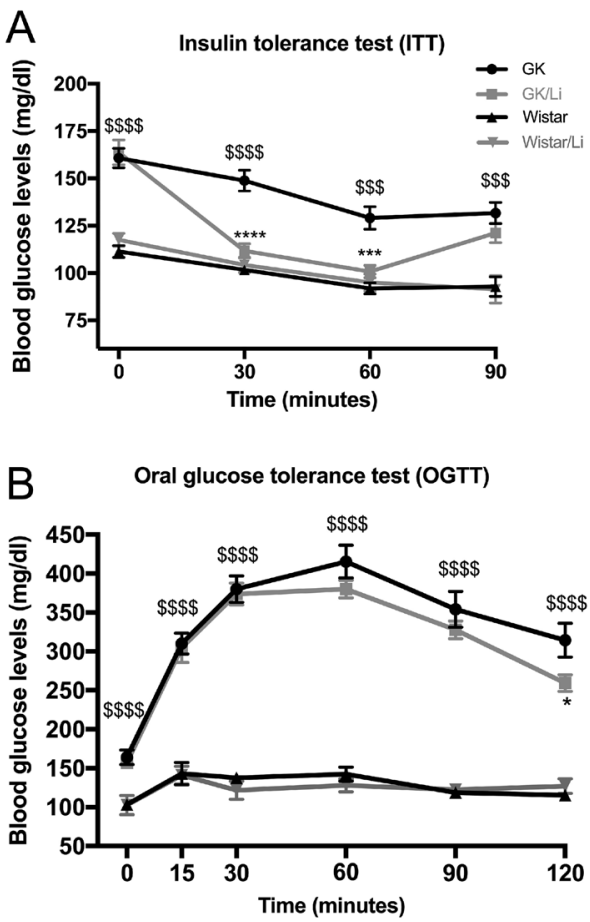

\section{Figure 2}

GSK3 inhibition improves insulin sensitivity in the GK rat. (A) Insulin tolerance test was performed in GK $(n=29)$, GK/Li $(n=28)$, Wistar $(n=9)$ and Wistar/Li $(n=7)$ rats after 5 weeks of treatment. (B) Oral glucose tolerance test was performed after 5 weeks of treatment in GK $(n=8)$, GK/Li $(n=14)$, Wistar $(n=6)$ and Wistar/Li rats $(n=6)$ rats. $* P<0.05$; $* * P<0.01 ; * * * P<0.001 ; * * * * P<0.0001$ compared to GK rats. Results are expressed as means \pm S.E.M. Two-way ANOVA with Tukey's multiple comparisons test was used for statistical analysis.

LiCl treatment significantly reduced the expression of these pro-inflammatory cytokines, although for TNF- $\alpha$, it did not reach statistical significance (Fig. 3A, B and C). Moreover, the expression of pro-inflammatory chemokines osteopontin, CXCL1, CCL2 and CCL3 was increased in GK islets compared to Wistar islets. Again, lithium treatment resulted in a significant diminution of mRNAs of these chemokines as shown in Fig. 3D, E, F and G. Other mediators of inflammation such as TLR-4 and TLR-2 and iNOS were also upregulated in GK islets, and their levels tended to be reduced in GK/Li rats compared to untreated GK rats (Fig. 3H, I and J). Additionally, the expression of pro-survival gene $\mathrm{BCl}-2$ was increased and that of pro-apoptotic gene Bax was decreased in GK/Li rats as a consequence of lithium treatment (Fig. $3 \mathrm{~K}$ and $\mathrm{L}$ ). Since $\mathrm{LiCl}$ was given in a systemic manner, we reasoned that its anti-inflammatory effects could also occur in other metabolically active tissues. To address this question, we evaluated the expression of inflammatory markers in insulin-sensitive tissues in GK, GK/Li and Wistar groups. In adipose tissue, CXCL1 and CCL3 mRNA levels were 
A

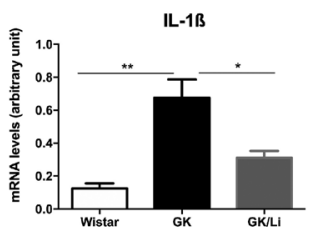

D

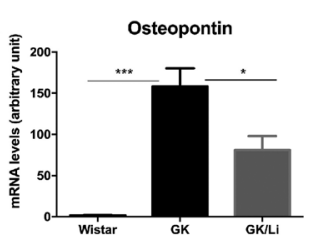

G
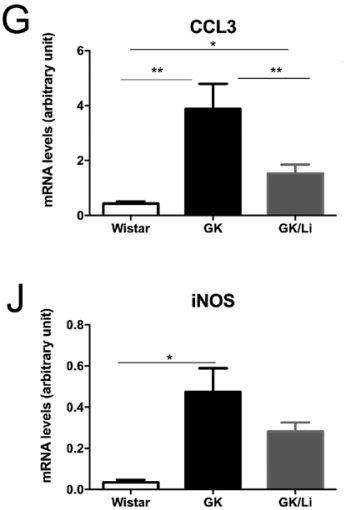

B

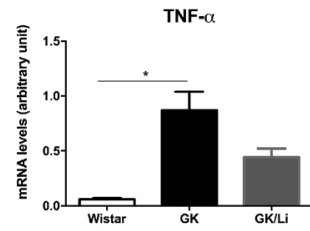

E

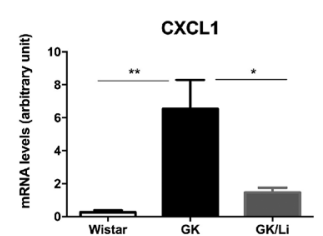

$\mathrm{H}$

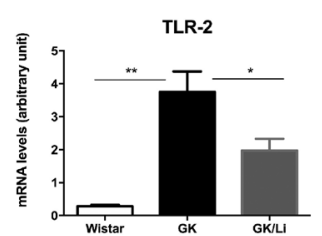

$\mathrm{K}$

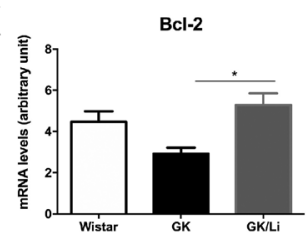

C

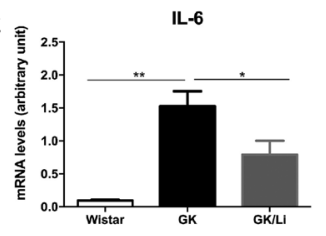

$\mathrm{F}$

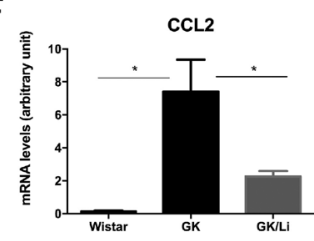

I

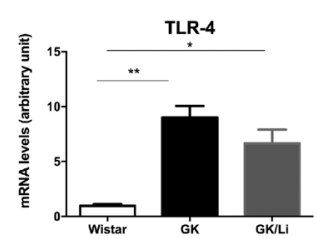

$\mathrm{L}$

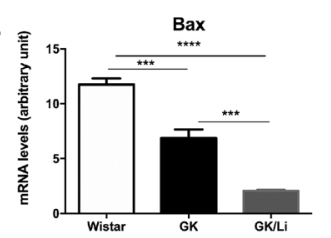

Figure 3

$\mathrm{LiCl}$ administration reduces the expression of pro-inflammatory cytokines and chemokines in GK islets. Pancreatic islets were isolated after 6 weeks of treatment, from GK $(n=13), \mathrm{GK} / \mathrm{Li}$ $(n=11)$ and Wistar $(n=6)$ rats. Total RNA was extracted from islets and quantitative real-time PCR was performed for the indicated genes, normalized to Cyclophilin A: (A) IL-1 $\beta$, (B) TNF- $\alpha,(C)$ IL-6, (D) Osteopontin, (E) CXCL1, (F) CCL2, (G) CCL3, (H) TLR-2, (I) TLR-4, (J) iNOS, (K) Bcl-2, (L) Bax. The experiments were performed in duplicates. $* P<0.05 ; * * P<0.01 ; * * * P<0.001 ; * * * * P<0.0001$. Results are expressed as means \pm S.E.M. One-way ANOVA followed by Tukey's multiple comparisons test was used for statistical analysis. significantly increased in GK compared to Wistar rats, while the increased expression of IL- $\beta$, IL- 6 and CCL 2 was not significant. $\mathrm{LiCl}$ consistently reduced the expression of pro-inflammatory cytokines and chemokines of adipose tissues of GK rats (Fig. 4A). In the muscle, IL-6, CXCL1 and CCL2 were upregulated in GK versus Wistar rats, and lithium tended to reduce their expression, without reaching statistical significance (Fig. 4B). In the liver, only CCL3 and osteopontin had their mRNA levels significantly increased in GK rats compared to Wistar rats, and lithium tended to reduce their expression (Fig. 4C).

\section{Lithium treatment improves the glucose-induced insulin secretion in GK islets}

Chronic inflammation is known to exert toxic effects on $\beta$ cell survival and function (Cnop et al. 2005, Varin et al. 2016). In order to evaluate the positive impact of the reduction of inflammation on the secretory function of islets, we measured the glucose-induced insulin secretion (GIIS) during static incubation experiments. As shown in Fig. 5A, lithium treatment reduced basal insulin secretion in GK islets. When expressed as glucose-induced insulin secretion over basal values, there was an almost two-fold increase in the insulin secretory response of GK/Li islets to glucose, compared to that of control GK islets (Fig. 5B).
Lithium treatment increases the pancreatic insulin content and partially reverses structural and morphological alteration of the endocrine pancreas in GK rats

In order to assess the impact of reduced inflammation on the structural alteration exhibited by the GK pancreas, we measured the $\beta$ cell-surface area in pancreatic sections of 16 weeks old GK/Li (11 weeks of treatment) and untreated GK littermates. We showed that after 11 weeks of treatment, the $\beta$ cell-surface area (which is spontaneously reduced by more than $50 \%$ in control GK rats compared to nondiabetic Wistar rats), tended to increase in GK/Li rats (Fig. $5 \mathrm{C}$ and $\mathrm{D})$. The pancreatic insulin content was significantly increased in 16-week-old GK/Li rats compared to untreated GK rats (Fig. 5E). As previously reported by our team and others, the reduced $\beta$ cell mass in adult GK rats is associated with a noticeable alteration in the architecture of a subpopulation of islets. Indeed, there is a marked islet fibrosis with $\beta$ cell depletion (Movassat et al. 1995, Koyama et al. 1998). Fibrosis is seen mostly in large islets, with signs of disorganization of mantle-core relationship (Movassat et al. 1995). Here, using Picrosirius Red staining, we confirmed the presence of a high number of fibrotic islets within the pancreatic sections of GK rats, while age-matched Wistar rats presented virtually no islet fibrosis. $\mathrm{LiCl}$ treatment 
A

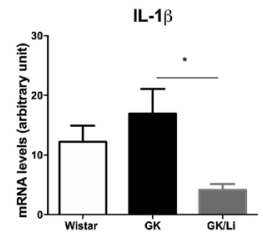

ADIPOSE TISSUE
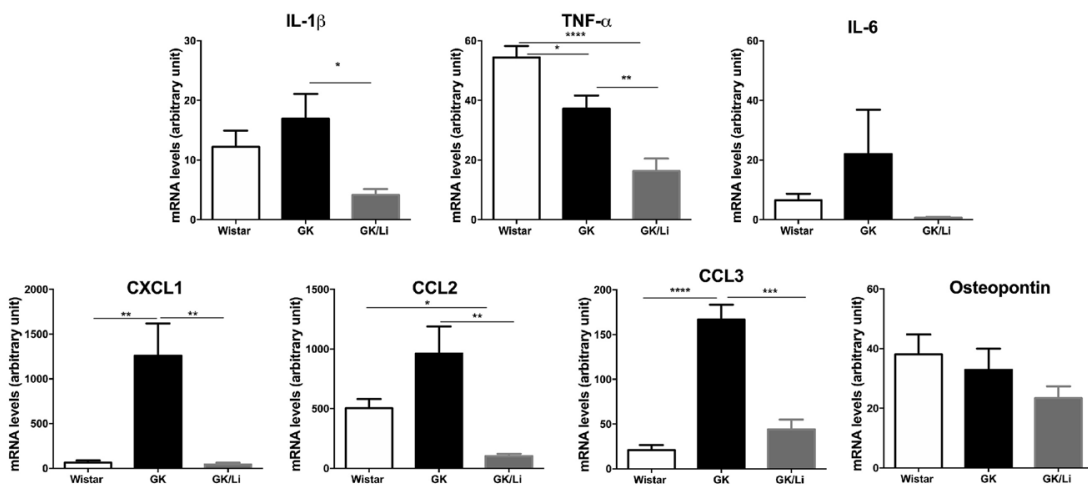

B
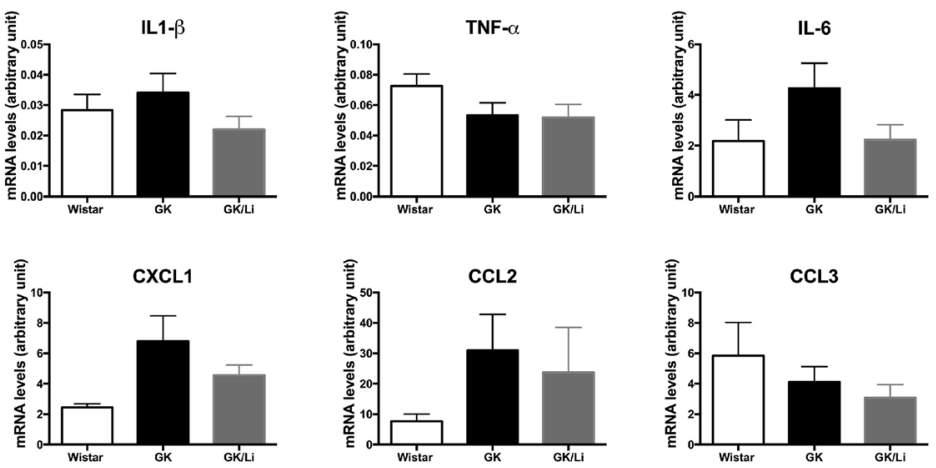

C
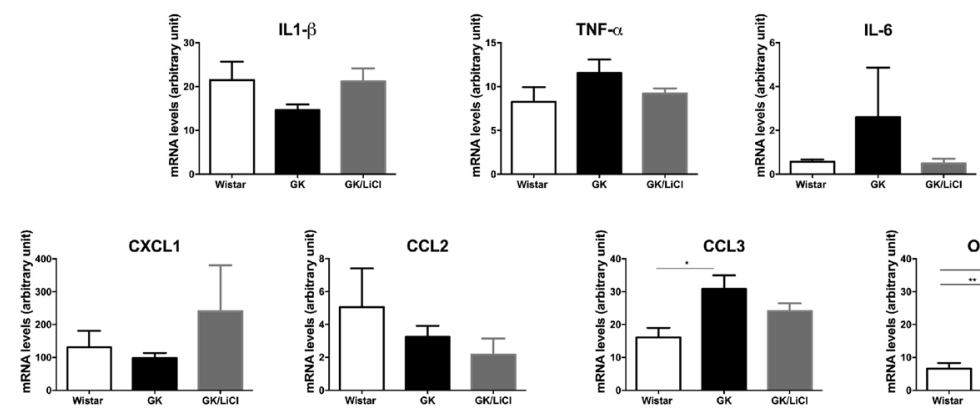

resulted in a $50 \%$ decrease in the number of fibrotic islets in the GK/Li group compared to GK group (Fig. 6A and B). Moreover, immunostaining for macrophage marker CD68 revealed a significant reduction in the number of islets with macrophage infiltration in GK/Li rats, compared to agematched untreated GK rats (Fig. 6C and D).

\section{Lithium treatment reduces hyperglycemia in GK rats with established diabetes}

In an additional set of experiments, GK rats with overt diabetes were treated with $\mathrm{LiCl}$ for 15 weeks. We show

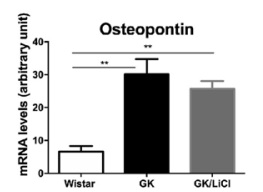

\section{Figure 4}

GSK3 inhibition reduces adipose tissue inflammation in GK rats. Real-time PCR was performed on samples from epididymal adipose tissue (A) muscle (B) and liver (C) from GK, GK/Li and Wistar rats after 6 weeks of treatment. qPCR was performed for the indicated genes, and normalized to HPRT1 for (A), to TBP for (B) and to Cyclophilin A for (C). Three to six animals were analyzed for each group represented in these figures. The experiments were performed in duplicates. Results are expressed as means \pm S.E.M. $\star P<0.05 ; * \star P<0.01 ; * * * P<0.001 ; * * * * P<0.0001$. One-way ANOVA followed by Tukey's multiple comparisons test was used for statistical analysis. that lithium treatment efficiently reduced the blood glucose level of diabetic GK rats (Fig. 7), suggesting that lithium treatment is not only useful for preventing the development of diabetes in the GK rat, but can also be an efficient means to treat animals with established diabetes.

\section{Direct implication of GSK3 in cytokine-induced islet inflammatory response}

Next, we sought to investigate the direct implication of GSK3 in the regulation of islet inflammation and to gain insight in the signaling pathways involved in GSK3-mediated 
B

A Glucose-induced insulin secretion

Glucose-induced insulin secretion

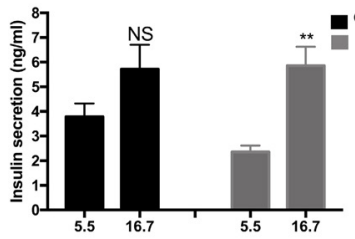

C

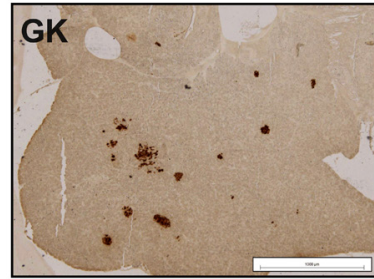

D
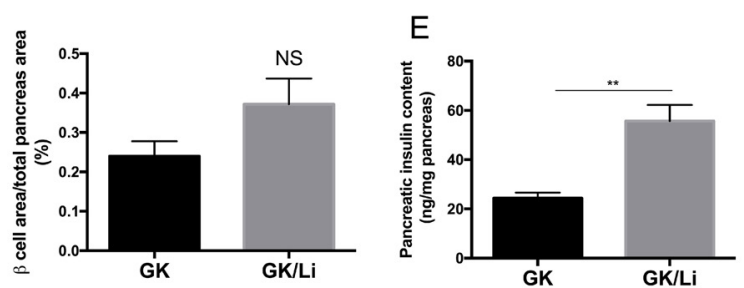

Figure 5

$\mathrm{LiCl}$ partially restores insulin secretion, pancreatic insulin content and the $\beta$ cell area in GK rats. (A and B) Pancreatic islets were isolated from GK $(n=5)$ and GK/Li $(n=6)$ rats, at 10 to 12 weeks of age. Islets were pre-incubated in $5.5 \mathrm{mM}$ glucose for $60 \mathrm{~min}$, followed by $90 \mathrm{~min}$ incubation in with 5.5 or $16.7 \mathrm{mM}$ glucose to measure basal and glucose-induced insulin secretion, respectively. The experiments were performed in quadruplicates. (C) $\beta$ cells were immunolocalized by insulin staining (brown). (D) Morphometric analysis of $\beta$ cells was performed at 16 weeks of age, after 11 weeks of treatment. The relative $\beta$ cell-surface area over total pancreatic area was measured. (E) The insulin content was determined after 11 weeks of treatment in GK and GK/Li rats. Five to eight animals were analyzed in each group. ${ }^{*} P<0.01$. Results are expressed as means \pm S.E.M. Unpaired Student $t$ test was used for statistical analysis. A full colour version of this figure is available at https://doi.org/10.1530/JOE-19-0239.

inflammatory response in human and rat islets. To address this question, we exposed islets from non-diabetic Wistar rats, INS-1 $\beta$ cells (clone 832/13) and human islets from cadaveric donors, to a combination of pro-inflammatory cytokine (IL1- $\beta$, TNF- $\alpha$ and IFN $\gamma$ - noted ' $C K$ '), a condition mimicking the inflammatory environment in type 1 (Grieco et al. 2014) and type 2 (Saldeen et al. 2001) diabetes. We characterized the pattern of cytokine and chemokine expression induced by pro-inflammatory cytokines in these cells and showed that rat islets exposed to CK had increased expression of IL1- $\beta$, TNF- $\alpha$, IL- 6 , iNOS and CXCL1 compared to untreated islets. Treatment of the islets with $\mathrm{LiCl}$ significantly reduced the expression of these cytokines (Fig. 8A). Similarly, in human islets, the exposure to CK resulted in the upregulation of the expression of IL1- $\beta$, TNF- $\alpha$, IL-6, iNOS and CCL2, and downregulation of the anti-inflammatory cytokine IL-10. It should be noted that we were not able to detect IL-10 in rat samples in any condition. In addition to $\mathrm{LiCl}$, and in order to confirm the implication of GSK3 in this process, we used SB216763, a more selective GSK3 inhibitor. Treatment of human islets with either $\mathrm{LiCl}$ or SB216763 reduced the cytokine-induced expression of pro-inflammatory markers and incremented the expression of IL-10 (Fig. 8B). Taken together, these results in rat and human islets provide direct evidence of the implication of GSK3 in islet inflammatory response. Islets are heterogeneous structures, composed of different endocrine cell types. In order to determine the specific response of $\beta$ cells to pro-inflammatory environment, we used the INS-1 $\beta$ cell line. INS- 1 cells exposed to the combination of pro-inflammatory cytokines showed increased expression of IL1- $\beta$, TNF- $\alpha$, IL-6, CXCL1, CCL2 and iNOS, suggesting a $\beta$ cell autonomous inflammatory response, following the exposure to a pro-inflammatory environment. The inhibition of GSK3 by $\mathrm{LiCl}$ significantly reduced the cytokine-induced expression of IL1- $\beta$, TNF- $\alpha$, CXCL1 and iNOS (Fig. 9A), demonstrating the implication of GSK3 in this response. Next, we sought to gain insight in the signaling pathways involved in GSK3-mediated inflammatory response. Members of the signal transducer and activator of transcription (STAT) family are known to play a central role in cellular inflammatory response (Beurel et al. 2008). We tested the implication of this pathway in INS- 1 cells exposed to CK. IFN $\gamma$ is the major cytokine known to be implicated in STAT 3 activation. Nevertheless, in order to maintain the same culture condition as the one we used for the previous experiments, we used the CK solution which already included IFN $\gamma$. We determined the kinetic of STAT3 activation by the evaluation of phospho-Tyr ${ }^{705}$. STAT3 levels. We showed that stimulation with the CK resulted in increased levels of phospho-Tyr ${ }^{705}$-STAT3, not significantly at $30 \mathrm{~min}$ following stimulation, but peaking at $2 \mathrm{~h}(P<0.01)$ and still maintained at $6 \mathrm{~h}$ post stimulation $(P<0.001)$ (Fig. 9B). Treatment with $\mathrm{LiCl}$ reduced phosphoTyr ${ }^{705}$-STAT3 levels, $2 \mathrm{~h}$ and $6 \mathrm{~h}$ post stimulation (Fig. 9B). These events implicated GSK3 $\beta$. Indeed, as expected, lithium treatment increased the levels of phospho-Ser9GSK3 $\beta$, the inactive form GSK3 $\beta$, confirming that GSK3 $\beta$ inhibitory effect of lithium was accountable for the reduction of phospho-Tyr ${ }^{705}$-STAT3 levels (Fig. 9B).

\section{Discussion}

Islet inflammation is one of the hallmarks of human T2D (Richardson et al. 2009, Kamata et al. 2014, 

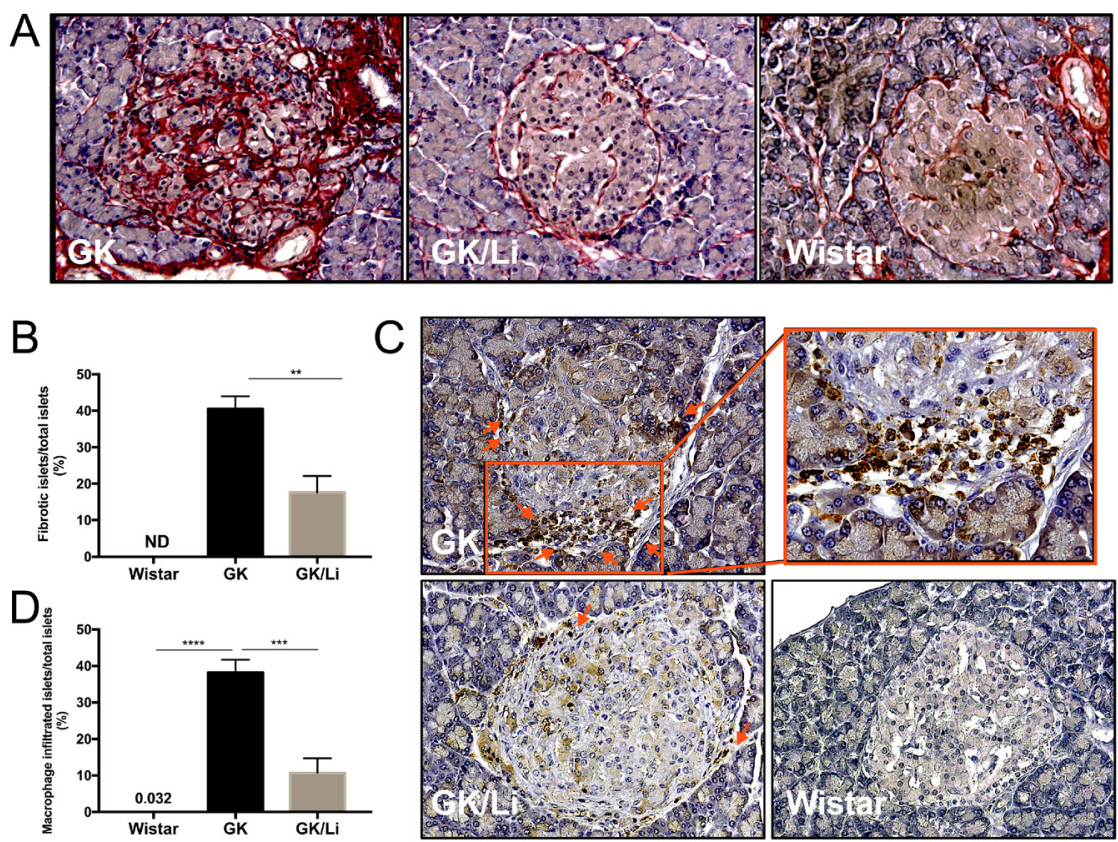

\section{Figure 6}

GSK3 inhibition reduces macrophage infiltration and islet fibrosis in the pancreas of GK rats. (A) After 6 weeks of treatment, pancreatic sections of GK $(n=5), \mathrm{GK} / \mathrm{Li}(n=5)$ and Wistar rats $(n=5)$ were stained with Picro Sirius Red Solution, followed by counterstaining with Papanicolau's solution. (B) Fibrosis scores were determined by calculating the percentage of fibrotic islets over total number of islets. No fibrotic islet was found in the pancreases from the Wistar group. (C) Immunohistochemistry was performed for macrophage marker CD68 (brown). Arrows show CD68 ${ }^{+}$cells. (D) Macrophage infiltration was calculated as the percentage of infiltrated islets (more than three macrophages) over total number of islets, in the pancreas of 11-week-old GK, after 6 weeks of treatment $(n=5)$, GK/Li $(n=5)$ and Wistar rats $(n=5) . * * P<0.01 ; * * * P<0.001$; $\star \star \star \star * P<0.0001$. Results are expressed as means \pm S.E.M. Unpaired Student $t$ test (B) and one-way ANOVA followed by Tukey's multiple comparisons test (D) were used for statistical analysis.
Eguchi \& Nagai 2017). In diabetic GK rats, islet inflammation is present and contributes to $\beta$ cell dysfunction (Homo-Delarche et al. 2006, Ehses et al. 2009). In recent years, GSK3 has emerged as an important regulator of immune response in various inflammatory and autoimmune diseases (Jope et al. 2007). However, the implication of GSK3 in diabetes-associated inflammation had not been investigated. Here, we show that targeting GSK3 significantly reduces islet inflammation and thereby improves $\beta$ cell function in GK rats. Martin and colleagues first established that GSK3 activity is necessary for full stimulation of the production of several pro-inflammatory cytokines, such as IL-6, IL-1 $\beta$ and TNF- $\alpha$, following stimulation of Toll-like receptors (TLR) in monocytes and peripheral blood mononuclear cells (Martin et al. 2005). As reported in a previous work (Ehses et al. 2009), in this study we confirm that the expression of a number of inflammatory mediators is upregulated in GK islets versus non-diabetic Wistar islets. Here we used lithium, a widely used inhibitor of GSK3 to investigate the impact of GSK3 inhibition in diabetes-associated inflammation. Lithium has been widely used in many studies as a pharmacological inhibitor of GSK3 (Noble et al. 2005, Makoukji et al. 2012, reviewed in King et al. 2014). Those studies demonstrated that lithium produces similar biological consequences as inhibition of GSK3 via other means (reviewed in O'Brien \& Klein 2009, Eldar-Finkelman \& Martinez 2011). Lithium has been used for decades for the treatment of bipolar disorder, and thus, could have translational potential to human T2D. We show for the first time that chronic treatment with lithium, resulted in decreased expression of key inflammation-associated cytokines and chemokines in GK islets. Moreover, decreased pro-inflammatory gene expression was associated with improved glucose-induced insulin secretion in GK islets. Acute treatment of control GK islets with $\mathrm{LiCl}$ had no effect on glucose-stimulated insulin secretion (data not shown), suggesting that improved islet function in GK/Li animals is mostly due to chronic effects of lithium, such as its impact on reducing inflammation. The GK rat is characterized by an early defect in $\beta$ cell mass which is persistent all throughout life (Movassat et al. 1995).

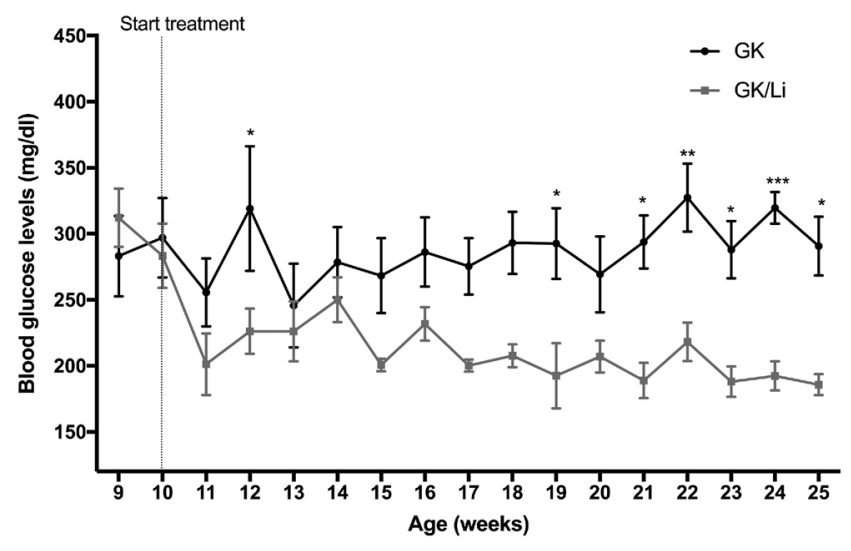

Figure 7

GSK3 inhibition reduces hyperglycemia in GK rat with established diabetes. Blood glucose levels in GK rats treated or not with LiCl (GK/Li, $n=8 ; G K, n=6)$ at the age of 10 weeks and for 15 consecutive weeks. $\star P<0.05 ; * * P<0.01 ; * * * P<0.001$. Results are expressed as means \pm S.E.M. Two-way ANOVA with Tukey's multiple comparisons test was used for statistical analysis.
(C) 2020 Society for Endocrinology Published by Bioscientifica Ltd. Printed in Great Britain 
A

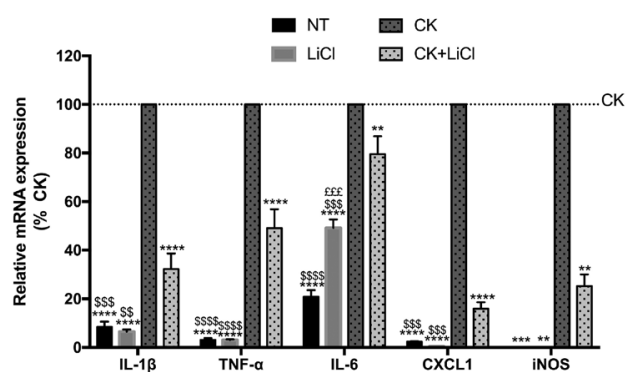

B

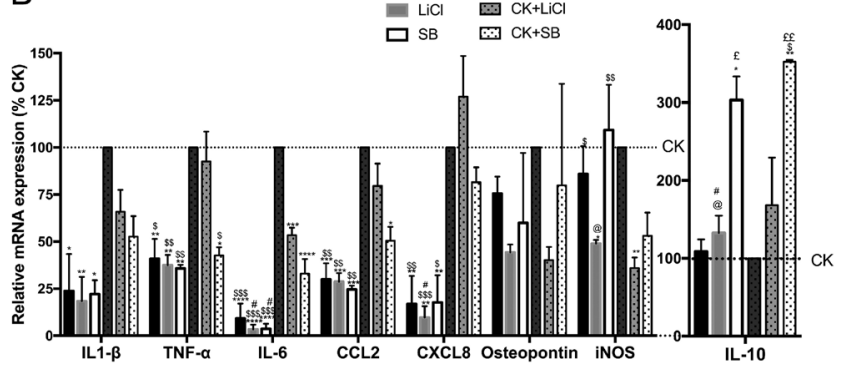

Figure 8

GSK3 inhibition reduces the cytokine-induced expression of inflammatory markers in rat and human islets. Pancreatic islets were isolated from Wistar rats (A) or human pancreas (B). After 24-h (rat islets) or 48-h (human islets) recovery in culture, they were pre-incubated overnight with $10 \mathrm{mM} \mathrm{LiCl}$ (LiCl), with $20 \mu \mathrm{M}$ SB216763 (SB), or not (NT). Batches of LiCl or SB216763 pre-treated islets were then treated for $8 \mathrm{~h}$ with a combination of TNF- $\alpha$, IFN $\gamma$ and IL-1 $\beta(C K+\mathrm{LiCl}$ or $\mathrm{CK}+\mathrm{SB})$. A batch of NT islets were treated for $8 \mathrm{~h}$ with a combination TNF- $\alpha$, IFN $\gamma$ and IL-1 $\beta$ (CK). Quantitative real-time PCR was performed on islets to evaluate the expression of pro-inflammatory markers. ${ }^{*} P<0.05 ; * \star P<0.01 ; * \star \star * P<0.001 ; * \star \star \star * P<0.0001$ compared to CK; $\$ P<0.05 ; \$ \$ P<0.01 ; \$ \$ P<0.001 ; \$ \$ \$ P<0.0001$ compared to $\mathrm{CK}+\mathrm{LiCl}$; f $P<0.05$; ff $P<0.01$; fff $P<0.001$ compared to NT; $\# P<0.05$ compared to $\mathrm{CK}+\mathrm{SB} ; @ P<0.05$ compared to SB216763. Results are expressed as means \pm S.E.M. One-way ANOVA followed by Tukey's multiple comparisons test was used for statistical analysis.

Chronic hyperglycemia appears only after weaning and worsens during the following weeks. In addition to decreased $\beta$ cell mass, adult GK pancreas exhibits a number of biochemical and structural alteration such as the development of fibrosis and with signs of disorganization of mantle-core relationship, in the majority of large islets (Movassat et al. 1995). These anatomical changes correlate with $\beta$ cell dysfunction and the development of overt diabetes in GK rats (Movassat et al. 1995, HomoDelarche et al. 2006). We show that lithium treatment causes significant improvement in morphological and structural characteristics of the GK pancreas. Indeed, the percentage of islets surrounded by macrophages was significantly reduced in GK/Li rats compared to untreated GK rats. Histological examination of pancreatic sections also revealed a clear reduction in the percentage of islet with fibrosis. Osteopontin has been implicated in macrophage infiltration in adipose tissue during obesity

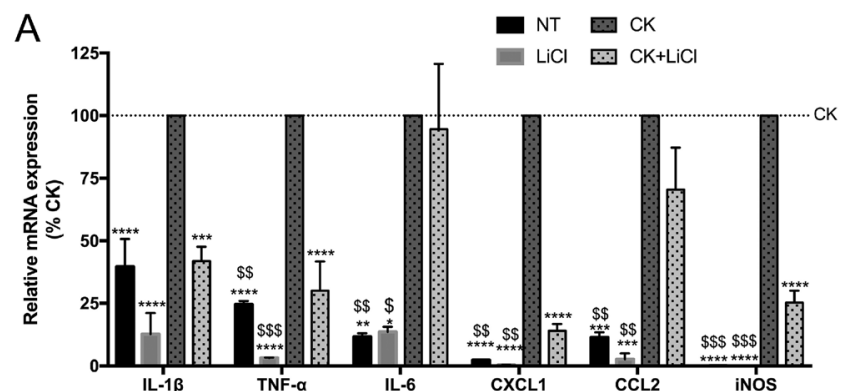

B
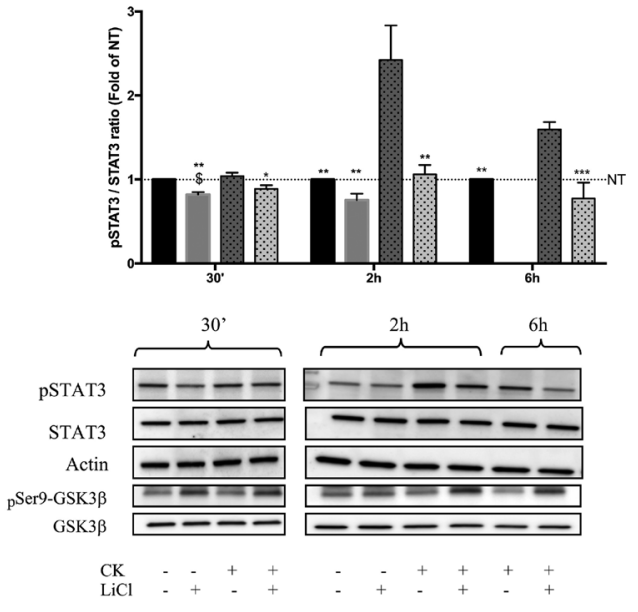

Figure 9

$\mathrm{LiCl}$ treatment reduces cytokine-induced expression of inflammatory markers in INS-1 beta cells. INS-1 cells (clone 832/13) were pre-treated for $1 \mathrm{~h}$ with $\mathrm{LiCl}(\mathrm{LiCl})$ or not (NT). (A) Batches of $\mathrm{LiCl}$ and NT cells were treated for $16 \mathrm{~h}$ with a combination of TNF- $\alpha$, IFN $\gamma$ and IL-1 $\beta(C K+\mathrm{LiCl})$ and (CK) respectively. Quantitative real-time PCR was performed on samples for the evaluation of mRNAs of pro-inflammatory markers. (B) Other INS-1 cells, pre-treated (LiCl group) or not (NT group) were exposed to a combination of cytokines (TNF- $\alpha$, IFN $\gamma$ and IL-1 $\beta$ ) for 30 min, 2 h or 6 h, and levels of GSK3 $\beta$, phospho-Ser9-GSK3 3 , STAT3 and phospho-Tyr ${ }^{705}$ STAT3 protein levels were determined. ${ }^{*} P<0.05$; $* * P<0.01$; $* \star * P<0.001$; $\star * * * P<0.0001$ compared to $C K ; \$ P<0.05 ; \$ P<0.01 ; \$ \$ P<0.001$ compared to $\mathrm{CK}+\mathrm{LiCl}$. Results are expressed as means \pm S.E.M. Four to six independent experiments were performed. One-way ANOVA followed by Tukey's multiple comparisons test was used for statistical analysis.

(Nomiyama et al. 2007). In this study, we showed a dramatic increase in osteopontin and CCL2 expression in GK islets compared to non-diabetic Wistar islets. Given the role of these molecules in the development of fibrosis (Zahradka et al. 2008, Zimmermann et al. 2011), their decreased expression following $\mathrm{LiCl}$ treatment could account for the improvement of islet fibrosis in the pancreas of GK/Li rats.

The effect of the chronic lithium treatment on the glycemic status of GK rats was striking.

This was achieved at a dosage of lithium that yielded sub-therapeutic plasmatic concentrations of lithium in rats. Indeed, at the end of the treatment, the blood glucose levels in GK/Li rats reached near-normal levels, in sharp contrast with age-matched untreated GK rats, 
which developed overt diabetes. Moreover, normal Hb1Ac values were recovered in GK/Li rats, reaching a level similar to that of Wistar animals. Lithium treatment proved more effective in reducing hyperglycemia, compared to other anti-diabetic agents such as GLP-1 and its analog Exendin-4 (Tourrel et al. 2002), the hypoglycemic sulfonylurea Glyclazide (Dachicourt et al. 1998), and the IL-1 $\beta$ receptor antagonist IL-1Ra (Ehses et al. 2009) previously tested in our local GK colony. More than one mechanism are certainly involved in the regulation of glucose metabolism by $\mathrm{LiCl}$ treatment. While here we clearly demonstrate the anti-inflammatory effects of the treatment in vivo, additional mechanisms involving insulin action and insulin production cannot be excluded. GSK3 is a negative regulator of insulin signaling pathway (Boucher et al. 2014). GSK3 expression and activity have been reported to be elevated in insulin target tissues (Eldar-Finkelman et al. 1999). In humans with T2D, GSK3 protein levels were increased in skeletal muscle, and this correlated with decreased insulin sensitivity (Nikoulina et al. 2000). Our evaluation of the whole-body insulin sensitivity through insulin tolerance tests revealed that lithium treatment improved insulin sensitivity in GK rats. We have not investigated insulin signaling at molecular level in muscle and adipose tissue in this study. Nevertheless, we believe that in addition to reduced islet inflammation, increased insulin sensitivity in metabolic tissues caused by $\mathrm{LiCl}$ treatment could contribute to the improvement of hyperglycemia in the GK rat. Such effects have been reported in other models of insulin resistance (Eldar-Finkelman et al. 1999, Nikoulina et al. 2000, Kim et al. 2015). GK rats exhibit also defective $\beta$ cell mass and function (Movassat et al. 2007). Another possible mechanism involved in the better glucose control in GK/Li rats is the effect of the treatment on the $\beta$ cell mass. We and others have previously reported that GSK3 is a negative regulator of $\beta$ cell growth and survival (Tanabe et al. 2008, Figeac et al. 2010, Liu et al. 2010). Canonical $\mathrm{Wnt} / \beta$ catenin pathway is proposed to be implicated in $\beta$ cell proliferation (Rulifson et al. 2007). GSK3 inhibition mimics the activation of $\mathrm{Wnt} / \beta$ catenin pathway. In keeping with this, we recently showed that inhibition of GSK3 $\beta$ with $\mathrm{LiCl}$ or its knockdown by specific morpholinooligonucleotides, stimulated $\beta$ cell regeneration in rat models of diabetes with severe $\beta$ cell deficiency (Figeac et al. 2010, 2012). In the present study, we show that at the end of the treatment, the pancreatic insulin store was significantly higher in GK/Li rats compared to that found in untreated GK rats. The $\beta$ cell surface area tended to increase in GK/Li rats and the islets seemed to be larger in this group compared to untreated GK group. The fact that lithium treatment prevents the development of fibrosis, and therefore, protects large islets from disintegration, contributes in part to the impression that more large islets are present in $\mathrm{GK} / \mathrm{Li}$ pancreas compared to untreated GK rats. Moreover, although we did not investigate $\beta$ cell proliferation in the present study, the increased $\beta$ cell proliferation induced by lithium, as we reported previously (Figeac et al. 2012) could be an additional factor contributing to the development of larger islets in the GK/Li group. Another finding was that in islets isolated from LiCl-treated rats, GIIS was improved. Interestingly, the effects of lithium on insulin secretion have been demonstrated long ago (Sjöholm et al. 1992, Sjöholm 1996), though in those works the implication of GSK3 in the improvement of insulin secretion induced by lithium have not been investigated. Indeed, the GSK3 inhibitory effect of lithium was only beginning to emerge at that time (Klein \& Melton 1996). Moreover, the total $\beta$ cell surface was also slightly increased in GK/Li rats. In addition, we showed an increased expression of pro-survival gene $\mathrm{Bcl}-2$ and decreased expression of pro-apoptotic Bax gene in the islets isolated from GK/Li rats compared to untreated GK rats. Thus, the partial reconstitution of pancreatic insulin content and $\beta$ cell number due to lithium treatment, might have participated to the improvement of glycemic control of the GK rat.

Regarding the ex vivo studies, using isolated islets, we were also able to provide direct evidence of the implication of GSK3 in the inflammatory response in both rat and human islets. We showed that GSK3 inhibition by either lithium or another selective GSK3 inhibitor (SB216763) reduced the expression of pro-inflammatory mediators by human and rat islets, demonstrating for the first time, the direct implication of this enzyme in islet autonomous inflammatory response. The activation of STAT3, an important transcription factor involved in cellular inflammatory response, has been shown to be regulated by GSK3 in astrocytes (Beurel et al. 2008). Here, we showed that STAT3 activation was hampered by GSK3 inhibitors, demonstrating the GSK3 dependency of STAT3 activation in $\beta$ cells. The in vitro conditions used in the present study somewhat resembled type 1 diabetes (Grieco et al. 2014), where autoimmune activation results in increased production of pro-inflammatory cytokines which are known to exert cytotoxic effects on $\beta$ cells (Cnop et al. 2005, Varin et al. 2016). Moreover, these conditions mimic also the inflammatory environment of the islets of T2D diabetic subjects. Increased expression of pro-inflammatory genes by the islets, in response to 
inflammatory milieu showed here, was in line with other reports (Grieco et al. 2014). This autonomous immune response participates to the exacerbation of inflammation and might contribute to the progression of type 1 and type 2 diabetes. Our results in human islets identified GSK3 as a potential target to counter the autonomous islet inflammatory response and could have clinical translation. Indeed, limiting the autonomous islet immune response would help to preserve islet survival and function after transplantation, thereby improving the clinical outcome of islet transplantation in patients with type 1 diabetes.

Because of the implication of GSK3 in multiple diseased conditions, several small molecules with GSK3 inhibitor properties have been developed (Eldar-Finkelman \& Martinez 2011). In comparison with lithium, they are more selective and can be used at lower concentrations than those needed for lithium. However, lithium has been used for the treatment of bipolar disorder for more than 50 years, with manageable side effects (Jope 2011, Beurel et al. 2015). We have previously demonstrated the innocuity of lithium treatment in neonate and adult Wistar rats (Figeac et al. 2010, 2012). The present study revealed for the first time that sub-therapeutic levels this FDA-approved drug effectively dampens the diabetes-associated inflammation, in a relevant model of T2D. Further pre-clinical and clinical investigations are warranted to test the potential of lithium and other GSK3 $\beta$ inhibitors as possible anti-inflammatory treatment in the context of diabetes and metabolic syndrome.

\section{Supplementary materials}

This is linked to the online version of the paper at https://doi.org/10.1530/ JOE-19-0239.

\section{Declaration of interest}

The authors declare that there is no conflict of interest that could be perceived as prejudicing the impartiality of the research reported.

\section{Funding}

C L Pitasi is a recipient of doctoral fellowship from CORDDIM, Région Ilede France. This work was supported in part by a grant from MSDAVENIR.

\section{References}

Agudo J, Ayuso E, Jimenez V, Casellas A, Mallol C, Salavert A, Tafuro S, Obach M, Ruzo A, Moya M, et al. 2012 Vascular endothelial growth factor-mediated islet hypervascularization and inflammation contribute to progressive reduction of $\beta$-cell mass. Diabetes $\mathbf{6 1}$ 2851-2861. (https://doi.org/10.2337/db12-0134)

Beurel E \& Jope RS 2008 Differential regulation of STAT family members by glycogen synthase kinase-3. Journal of Biological Chemistry $\mathbf{2 8 3}$ 21934-21944. (https://doi.org/10.1074/jbc.M802481200)

Beurel E, Grieco SF \& Jope RS 2015 Glycogen synthase kinase-3 (GSK3): regulation, actions, and diseases. Pharmacology and Therapeutics 148 114-131. (https://doi.org/10.1016/j.pharmthera.2014.11.016)

Boucher J, Kleinridders A \& Kahn CR 2014 Insulin receptor signaling in normal and insulin-resistant states. Cold Spring Harbor Perspectives in Biology 6 a009191. (https://doi.org/10.1101/cshperspect.a009191)

Bucher P, Mathe Z, Morel P, Bosco D, Andres A, Kurfuest M, Friedrich O, Raemsch-Guenther N, Buhler LH \& Berney T 2005 Assessment of a novel two-component enzyme preparation for human islet isolation and transplantation. Transplantation 79 91-97. (https://doi. org/10.1097/01.tp.0000147344.73915.c8)

Cnop M, Welsh N, Jonas JC, Jörns A, Lenzen S \& Eizirik DL 2005 Mechanisms of pancreatic beta-cell death in type 1 and type 2 diabetes: many differences, few similarities. Diabetes 54 (Supplement 2) S97-S107. (https://doi.org/10.2337/diabetes.54.suppl_2.s97)

Cuzzocrea S, Mazzon E, Di Paola R, Muià C, Crisafulli C, Dugo L, Collin M, Britti D, Caputi AP \& Thiemermann C 2006 Glycogen synthase kinase-3beta inhibition attenuates the degree of arthritis caused by type II collagen in the mouse. Clinical Immunology $\mathbf{1 2 0}$ 57-67. (https://doi.org/10.1016/j.clim.2006.03.005)

Dachicourt N, Bailbé D, Gangnerau MN, Serradas P, Ravel D \& Portha B 1998 Effect of gliclazide treatment on insulin secretion and beta-cell mass in non-insulin dependent diabetic Goto-Kakisaki rats. European Journal of Pharmacology 361 243-251. (https://doi.org/10.1016/s00142999(98)00718-3)

Dalmas E, Clément K \& Guerre-Millo M 2011 Defining macrophage phenotype and function in adipose tissue. Trends in Immunology $\mathbf{3 2}$ 307-314. (https://doi.org/10.1016/j.it.2011.04.008)

Donath MY, Schumann DM, Faulenbach M, Ellingsgaard H, Perren A \& Ehses JA 2008 Islet inflammation in type 2 diabetes: from metabolic stress to therapy. Diabetes Care 31 (Supplement 2) S161-S164. (https://doi.org/10.2337/dc08-s243)

Donath MY, Böni-Schnetzler M, Ellingsgaard H \& Ehses JA 2009 Islet inflammation impairs the pancreatic beta-cell in type 2 diabetes. Physiology 24 325-331. (https://doi.org/10.1152/ physiol.00032.2009)

Dugo L, Collin M, Allen DA, Patel NSA, Bauer I, Mervaala EMA, Louhelainen M, Foster SJ, Yaqoob MM \& Thiemermann C 2005 GSK3beta inhibitors attenuate the organ injury/dysfunction caused by endotoxemia in the rat. Critical Care Medicine 33 1903-1912. (https:// doi.org/10.1097/01.ccm.0000178350.21839.44)

Eguchi K \& Nagai R 2017 Islet inflammation in type 2 diabetes and physiology. Journal of Clinical Investigation 127 14-23. (https://doi. org/10.1172/JCI88877)

Ehses JA, Perren A, Eppler E, Ribaux P, Pospisilik JA, Maor-Cahn R, Gueripel X, Ellingsgaard H, Schneider MKJ, Biollaz G, et al. 2007 Increased number of islet-associated macrophages in type 2 diabetes. Diabetes 56 2356-2370. (https://doi.org/10.2337/db06-1650)

Ehses JA, Lacraz G, Giroix MH, Schmidlin F, Coulaud J, Kassis N, Irminger JC, Kergoat M, Portha B, Homo-Delarche F, et al. 2009 IL-1 antagonism reduces hyperglycemia and tissue inflammation in the type 2 diabetic GK rat. PNAS 106 13998-14003. (https://doi. org/10.1073/pnas.0810087106)

Eldar-Finkelman H 2002 Glycogen synthase kinase 3: an emerging therapeutic target. Trends in Molecular Medicine 8 126-132. (https:// doi.org/10.1016/S1471-4914(01)02266-3)

Eldar-Finkelman H \& Martinez A 2011 GSK-3 inhibitors: preclinical and clinical focus on CNS. Frontiers in Molecular Neuroscience 4 32. (https:// doi.org/10.3389/fnmol.2011.00032)

Eldar-Finkelman H, Schreyer SA, Shinohara MM, LeBoeuf RC \& Krebs EG 1999 Increased glycogen synthase kinase-3 activity in diabetes- and https://joe.bioscientifica.com

https://doi.org/10.1530/JOE-19-0239 (c) 2020 Society for Endocrinology Published by Bioscientifica Ltd. Printed in Great Britain 
obesity-prone C57BL/6J mice. Diabetes 48 1662-1666. (https://doi. org/10.2337/diabetes.48.8.1662)

Esser N, Paquot N \& Scheen AJ 2015 Anti-inflammatory agents to treat or prevent type 2 diabetes, metabolic syndrome and cardiovascular disease. Expert Opinion on Investigational Drugs 24 283-307. (https:// doi.org/10.1517/13543784.2015.974804)

Figeac F, Uzan B, Faro M, Chelali N, Portha B \& Movassat J 2010 Neonatal growth and regeneration of beta-cells are regulated by the Wnt/betacatenin signaling in normal and diabetic rats. American Journal of Physiology: Endocrinology and Metabolism 298 E245-E256. (https://doi. org/10.1152/ajpendo.00538.2009)

Figeac F, Ilias A, Bailbe D, Portha B \& Movassat J 2012 Local in vivo GSK3 $\beta$ knockdown promotes pancreatic $\beta$ cell and acinar cell regeneration in 90\% pancreatectomized rat. Molecular Therapy 20 1944-1952. (https://doi.org/10.1038/mt.2012.112)

Goto Y, Kakizaki M \& Masaki N 1976 Production of spontaneous diabetic rats by repetition of selective breeding. Tohoku Journal of Experimental Medicine 119 85-90. (https://doi.org/10.1620/tjem.119.85)

Grieco FA, Moore F, Vigneron F, Santin I, Villate O, Marselli L, Rondas D, Korf H, Overbergh L, Dotta F, et al. 2014 IL-17A increases the expression of proinflammatory chemokines in human pancreatic islets. Diabetologia 57 502-511. (https://doi.org/10.1007/s00125-013-3135-2)

Hanak AS, Chevillard L, El Balkhi S, Risède P, Peoc'h K \& Mégarbane B 2015 Study of blood and brain lithium pharmacokinetics in the rat according to three different modalities of poisoning. Toxicological Sciences 143 185-195. (https://doi.org/10.1093/toxsci/kfu224)

Homo-Delarche F, Calderari S, Irminger JC, Gangnerau MN, Coulaud J, Rickenbach K, Dolz M, Halban P, Portha B \& Serradas P 2006 Islet inflammation and fibrosis in a spontaneous model of Type 2 diabetes, the GK rat. Diabetes 55 1625-1633. (https://doi.org/10.2337/ db05-1526)

Jope RS 2011 Glycogen synthase kinase-3 in the etiology and treatment of mood disorders. Frontiers in Molecular Neuroscience 4 16. (https:// doi.org/10.3389/fnmol.2011.00016)

Jope RS, Yuskaitis CJ \& Beurel E 2007 Glycogen synthase Kinase-3 (GSK3): inflammation, diseases, and therapeutics. Neurochemical Research 32 577-595. (https://doi.org/10.1007/s11064-006-9128-5)

Kamata K, Mizukami H, Inaba W, Tsuboi K, Tateishi Y, Yoshida T \& Yagihashi S 2014 Islet amyloid with macrophage migration correlates with augmented $\beta$-cell deficits in type 2 diabetic patients. Amyloid 21 191-201. (https://doi.org/10.3109/13506129.2014.937857)

Kim KM, Lee KS, Lee GY, Jin H, Durrance ES, Park HS, Choi SH, Park KS, Kim YB, Jang HC, et al. 2015 Anti-diabetic efficacy of KICG1338, a novel glycogen synthase kinase-3 $\beta$ inhibitor, and its molecular characterization in animal models of type 2 diabetes and insulin resistance. Molecular and Cellular Endocrinology 409 1-10. (https://doi. org/10.1016/j.mce.2015.03.011)

King MK, Pardo M, Cheng Y, Downey K, Jope RS \& Beurel E 2014 Glycogen synthase kinase-3 inhibitors: rescuers of cognitive impairments. Pharmacology and Therapeutics 141 1-12. (https://doi. org/10.1016/j.pharmthera.2013.07.010)

Klein PS \& Melton DA 1996 A molecular mechanism for the effect of lithium on development. PNAS 93 8455-8459. (https://doi. org/10.1073/pnas.93.16.8455)

Koyama M, Wada R, Sakuraba H, Mizukami H \& Yagihashi S 1998 Accelerated loss of islet beta cells in sucrose-fed Goto-Kakizaki rats, a genetic model of non-insulin-dependent diabetes mellitus. American Journal of Pathology 153 537-545. (https://doi.org/10.1016/s00029440(10)65596-4)

Lacraz G, Giroix MH, Kassis N, Coulaud J, Galinier A, Noll C, Cornut M, Schmidlin F, Paul JL, Janel N, et al. 2009 Islet endothelial activation and oxidative stress gene expression is reduced by IL-1RA treatment in the type 2 diabetic GK rat. PLOS ONE 4 e6963. (https://doi. org/10.1371/journal.pone.0006963)

Larsen CM, Faulenbach M, Vaag A, Vølund A, Ehses JA, Seifert B, Mandrup-Poulsen T \& Donath MY 2007 Interleukin-1-receptor antagonist in type 2 diabetes mellitus. New England Journal of Medicine 356 1517-1526.

Liu Y, Tanabe K, Baronnier D, Patel S, Woodgett J, Cras-Méneur C $\&$ Permutt MA 2010 Conditional ablation of GSK-3 $\beta$ in islet beta cells results in expanded mass and resistance to fat feedinginduced diabetes in mice. Diabetologia 53 2600-2610. (https://doi. org/10.1007/s00125-010-1882-x)

Liu JJ, Raynal S, Bailbé D, Gausseres B, Carbonne C, Autier V, Movassat J, Kergoat M \& Portha B 2015 Expression of the kynurenine pathway enzymes in the pancreatic islet cells. Activation by cytokines and glucolipotoxicity. Biochimica et Biophysica Acta 1852 980-991. (https://doi.org/10.1016/j.bbadis.2015.02.001)

Maedler K, Dharmadhikari G, Schumann DM \& Størling J 2009 Interleukin-1 beta targeted therapy for type 2 diabetes. Expert Opinion on Biological Therapy 9 1177-1188. (https://doi. org/10.1517/14712590903136688)

Makoukji J, Belle M, Meffre D, Stassart R, Grenier J, Shackleford G, Fledrich R, Fonte C, Branchu J, Goulard M, et al. 2012 Lithium enhances remyelination of peripheral nerves. PNAS 109 3973-3978. (https://doi.org/10.1073/pnas.1121367109)

Malozowski S \& Sahlroot JT 2007 Interleukin-1-receptor antagonist in type 2 diabetes mellitus. New England Journal of Medicine 357 302-303; author reply 303. (https://doi.org/10.1056/ NEJMc071324)

Mandrup-Poulsen T 2018 Immunometabolism in 2017: metabolism and the inflammasome in health and ageing. Nature Reviews: Endocrinology 14 72-74. (https://doi.org/10.1038/nrendo.2017.175)

Martin M, Rehani K, Jope RS \& Michalek SM 2005 Toll-like receptor mediated cytokine production is differentially regulated by glycogen synthase kinase 3. Nature Immunology 6 777-784. (https://doi. org/10.1038/ni1221)

Movassat J, Saulnier C \& Portha B 1995 Beta-cell mass depletion precedes the onset of hyperglycaemia in the GK rat, a genetic model of non-insulindependent diabetes mellitus. Diabete and Metabolisme 21 365-370.

Movassat J, Calderari S, Fernández E, Martín MA, Escrivá F, Plachot C, Gangnerau MN, Serradas P, Alvarez C \& Portha B 2007 Type 2 diabetes - a matter of failing beta-cell neogenesis? Clues from the GK rat model. Diabetes, Obesity and Metabolism 9 (Supplement 2) 187-195. (https://doi.org/10.1111/j.1463-1326.2007.00786.x)

Nikoulina SE, Ciaraldi TP, Mudaliar S, Mohideen P, Carter L \& Henry RR 2000 Potential role of glycogen synthase kinase-3 in skeletal muscle insulin resistance of type 2 diabetes. Diabetes 49 263-271. (https:// doi.org/10.2337/diabetes.49.2.263)

Noble W, Planel E, Zehr C, Olm V, Meyerson J, Suleman F, Gaynor K, Wang L, LaFrancois J, Feinstein B, et al. 2005 Inhibition of glycogen synthase kinase- 3 by lithium correlates with reduced tauopathy and degeneration in vivo. PNAS 102 6990-6995. (https://doi.org/10.1073/ pnas.0500466102)

Nomiyama T, Perez-Tilve D, Ogawa D, Gizard F, Zhao Y, Heywood EB, Jones KL, Kawamori R, Cassis LA, Tschöp MH, et al. 2007 Osteopontin mediates obesity-induced adipose tissue macrophage infiltration and insulin resistance in mice. Journal of Clinical Investigation $\mathbf{1 1 7}$ 2877-2888. (https://doi.org/10.1172/JCI31986)

O'Brien WT \& Klein PS 2009 Validating GSK3 as an in vivo target of lithium action. Biochemical Society Transactions 37 1133-1138. (https://doi.org/10.1042/BST0371133)

Omata N, Murata T, Takamatsu S, Maruoka N, Mitsuya H, Yonekura Y, Fujibayashi Y \& Wada Y 2008 Neuroprotective effect of chronic lithium treatment against hypoxia in specific brain regions with upregulation of cAMP response element binding protein and brainderived neurotrophic factor but not nerve growth factor: comparison with acute lithium treatment. Bipolar Disorders 10 360-368. (https:// doi.org/10.1111/j.1399-5618.2007.00521.x)

Portha B, Lacraz G, Kergoat M, Homo-Delarche F, Giroix MH, Bailbé D, Gangnerau MN, Dolz M, Tourrel-Cuzin C \& Movassat J 2009 The GK rat beta-cell: a prototype for the diseased human beta-cell in type 2 https://joe.bioscientifica.com https://doi.org/10.1530/JOE-19-0239 (c) 2020 Society for Endocrinology Published by Bioscientifica Ltd. Printed in Great Britain 
diabetes? Molecular and Cellular Endocrinology 297 73-85. (https://doi. org/10.1016/j.mce.2008.06.013)

Richardson SJ, Willcox A, Bone AJ, Foulis AK \& Morgan NG 2009 Isletassociated macrophages in type 2 diabetes. Diabetologia 521686 1688. (https://doi.org/10.1007/s00125-009-1410-z)

Ricordi C, Lacy PE, Finke EH, Olack BJ \& Scharp DW 1988 Automated method for isolation of human pancreatic islets. Diabetes 37 413-420. (https://doi.org/10.2337/diab.37.4.413)

Rulifson IC, Karnik SK, Heiser PW, Berge D ten, Chen H, Gu X, Taketo MM, Nusse R, Hebrok M \& Kim SK 2007 Wnt signaling regulates pancreatic $\beta$ cell proliferation. PNAS 104 6247-6252. (https://doi.org/10.1073/pnas.0701509104)

Saldeen J, Lee JC \& Welsh N 2001 Role of p38 mitogen-activated protein kinase (p38 MAPK) in cytokine-induced rat islet cell apoptosis. Biochemical Pharmacology 61 1561-1569. (https://doi.org/10.1016/ s0006-2952(01)00605-0)

Scheen AJ, Esser N \& Paquot N 2015 Antidiabetic agents: potential anti-inflammatory activity beyond glucose control. Diabetes and Metabolism 41 183-194. (https://doi.org/10.1016/j.diabet.2015.02.003)

Sjöholm A 1996 Lithium stimulation of rat pancreatic beta-cell replication is mediated through pertussis toxin-sensitive GTP-binding proteins and occurs independently of Ca2+ influx, cAMP, or protein kinase C activation. Diabetes 45 1057-1062. (https://doi.org/10.2337/ diab.45.8.1057)

Sjöholm A, Welsh N \& Hellerström C 1992 Lithium increases DNA replication, polyamine content, and insulin secretion by rat pancreatic beta-cells. American Journal of Physiology 262 C391-C395. (https://doi.org/10.1152/ajpcell.1992.262.2.C391)

Talab SS, Emami H, Elmi A, Nezami BG, Assa S, Deroee AF, Daneshmand A, Tavangar SM \& Dehpour AR 2010 Chronic lithium treatment protects the rat kidney against ischemia/reperfusion injury: the role of nitric oxide and cyclooxygenase pathways. European Journal of Pharmacology 647 171-177. (https://doi.org/10.1016/j.ejphar.2010.08.036)
Tanabe K, Liu Z, Patel S, Doble BW, Li L, Cras-Méneur C, Martinez SC, Welling CM, White MF, Bernal-Mizrachi E, et al. 2008 Genetic deficiency of glycogen synthase kinase-3beta corrects diabetes in mouse models of insulin resistance. PLoS Biology 6 e37. (https://doi. org/10.1371/journal.pbio.0060037)

Tourrel C, Bailbe D, Lacorne M, Meile MJ, Kergoat M \& Portha B 2002 Persistent improvement of type 2 diabetes in the Goto-Kakizaki rat model by expansion of the beta-cell mass during the prediabetic period with glucagon-like peptide- 1 or exendin-4. Diabetes 51 1443-1452. (https://doi.org/10.2337/ diabetes.51.5.1443)

Varin EM, Wojtusciszyn A, Broca C, Muller D, Ravier MA, Ceppo F, Renard E, Tanti JF \& Dalle S 2016 Inhibition of the MAP3 kinase Tpl2 protects rodent and human $\beta$-cells from apoptosis and dysfunction induced by cytokines and enhances anti-inflammatory actions of exendin-4. Cell Death and Disease 7 e2065. (https://doi.org/10.1038/ cddis.2015.399)

Westwell-Roper CY, Ehses JA \& Verchere CB 2014 Resident macrophages mediate islet amyloid polypeptide-induced islet IL-1 $\beta$ production and $\beta$-cell dysfunction. Diabetes 63 1698-1711. (https://doi.org/10.2337/ db13-0863)

Whittle BJR, Varga C, Pósa A, Molnár A, Collin M \& Thiemermann C 2006 Reduction of experimental colitis in the rat by inhibitors of glycogen synthase kinase-3beta. British Journal of Pharmacology 147 575-582. (https://doi.org/10.1038/sj.bjp.0706509)

Zahradka P 2008 Novel role for osteopontin in cardiac fibrosis. Circulation Research 102 270-272. (https://doi.org/10.1161/ CIRCRESAHA.107.170555)

Zimmermann HW \& Tacke F 2011 Modification of chemokine pathways and immune cell infiltration as a novel therapeutic approach in liver inflammation and fibrosis. Inflammation and Allergy Drug Targets 10 509-536. (https://doi. org/10.2174/187152811798104890)

Received in final form 4 October 2019

Accepted 10 October 2019

Accepted Manuscript published online 10 October 2019 (c) 2020 Society for Endocrinology Published by Bioscientifica Ltd. 